\title{
Reverse-genetics studies of IncRNAs—what we have learnt and paths forward
}

\author{
Fan Gao, Ye Cai, Philipp Kapranov ${ }^{*}$ and Dongyang $\mathrm{Xu}^{*}$
}

\begin{abstract}
Long non-coding RNAs (IncRNAs) represent a major fraction of the transcriptome in multicellular organisms. Although a handful of well-studied IncRNAs are broadly recognized as biologically meaningful, the fraction of such transcripts out of the entire collection of IncRNAs remains a subject of vigorous debate. Here we review the evidence for and against biological functionalities of IncRNAs and attempt to arrive at potential modes of IncRNA functionality that would reconcile the contradictory conclusions. Finally, we discuss different strategies of phenotypic analyses that could be used to investigate such modes of IncRNA functionality.
\end{abstract}

\section{Introduction}

At the beginning of this century, the central dogma of biology that posits genetic information flow from DNA to RNA to protein was challenged by the discovery of pervasive transcription in the human genome $[1,2]$. Long non-coding (lnc) RNAs account for most of the complexity of human transcriptome [3] and represent transcripts over 200 nucleotides in length [4] with no obvious protein-coding potential and a number of additional features (i.e., abundance, sequence conservation, splicing efficiency, subcellular localization, and others) that distinguish them from the canonical realm of protein-coding mRNAs [3, 5-7]. In the past decade, biological functions and molecular mechanisms of lncRNAs have attracted significant interest from the scientific community [8-12]. Although a number of lncRNAs have been associated with diverse biological processes and functions [13-15], for most part, these transcripts remain enigmatic. The most critical and yet the most controversial issue centers on biological significance of the lncRNA class of transcripts and the fraction of truly functional members it contains. Indeed, there is a growing body of contradictory evidence based on reverse-genetics assays that either supports or questions the broad biological functionality of

\footnotetext{
* Correspondence: philippk08@hotmail.com; xudongyang@hqu.edu.cn Institute of Genomics, School of Biomedical Sciences, Huaqiao University, 201 Pan-Chinese S \& T Building, 668 Jimei Road, Xiamen 361021, China
}

this class of RNAs as described below. This leads to a great deal of confusion while also fueling the debate about functionality of these transcripts. One side in this debate argues that most of the currently annotated lncRNAs are not functional and represent spurious byproducts of mRNA biogenesis, leaky transcription, or other processes that confer no fitness advantage [16-20]. Consistent with these views, recent in vivo studies with knockouts of multiple lncRNAs reported no observable phenotypes [21-31]. Moreover, the biological functions of IncRNAs observed in different studies are often controversial, even with regard to some transcripts that are considered as the "gold standards" by the community (see below for details). Here, we will review these controversial observations and attempt to provide a theoretical framework that could potentially reconcile them. Finally, we will review emerging solutions based on the lessons learnt from previous reverse-genetics studies and novel experimental approaches that could answer the question of the biological relevance of lncRNAs.

\section{Evidence supporting the biological roles of IncRNAs}

Ample body of research based on a variety of techniques supports the notion that lncRNAs do play biological roles in a variety of biological processes. Below, we attempt to review and summarize the main outcomes of these studies in the context of the different reverse- 
genetics (Fig. 1) and evolutionary approaches employed. While in this review we focus on techniques that directly address biological relevance of lncRNAs, clues to their biological importance can also be gleaned from understanding their mechanisms of function at the molecular level and therefore we would like to direct the reader to several reviews published recently on this topic [8-11, $13-15,104,105]$.

\section{RNA targeting}

Methods that specifically target an RNA molecule without altering its DNA sequence or transcription represent the most direct means of answering the question of the functionality of an IncRNA transcript per se without the potential confounding effects caused by disruption of an important DNA element or hampering progression of the RNA polymerase complex (see below) (Fig. 1). Phenotypic assays based on depletion of lncRNAs using two such technologies-RNAi or antisense oligos (ASOs)-represent perhaps the majority of the empirical evidence supporting the functionality of these transcripts. Indeed, both RNAi, either based on transfected siRNAs or endogenously expressed shRNAs, and ASOs have been used widely to show phenotypic consequences of depleting various types of lncRNAs. Below, we provide examples of such studies for individual transcripts that represent various types of lncRNAs that could be differentiated based on the form of the apparent functional product, e.g., spliced or unspliced and polyadenylated or non-polyadenylated, and subcellular localization (nuclear or cytosolic).

Knockdown of a nuclear unspliced polyA+ IncRNA Neat 1 by RNAi led to ablation of paraspeckles, suggesting the essential role of this IncRNA in the formation of these subnuclear compartments [106]. Knockdown of an unspliced, polyA - nuclear transcript $V A D$ belonging to a class of very long intergenic non-coding RNAs (vlincRNAs) using transfected siRNAs has demonstrated importance of this lncRNA for the maintenance of cellular senescence [107]. RNAi-mediated knockdown of

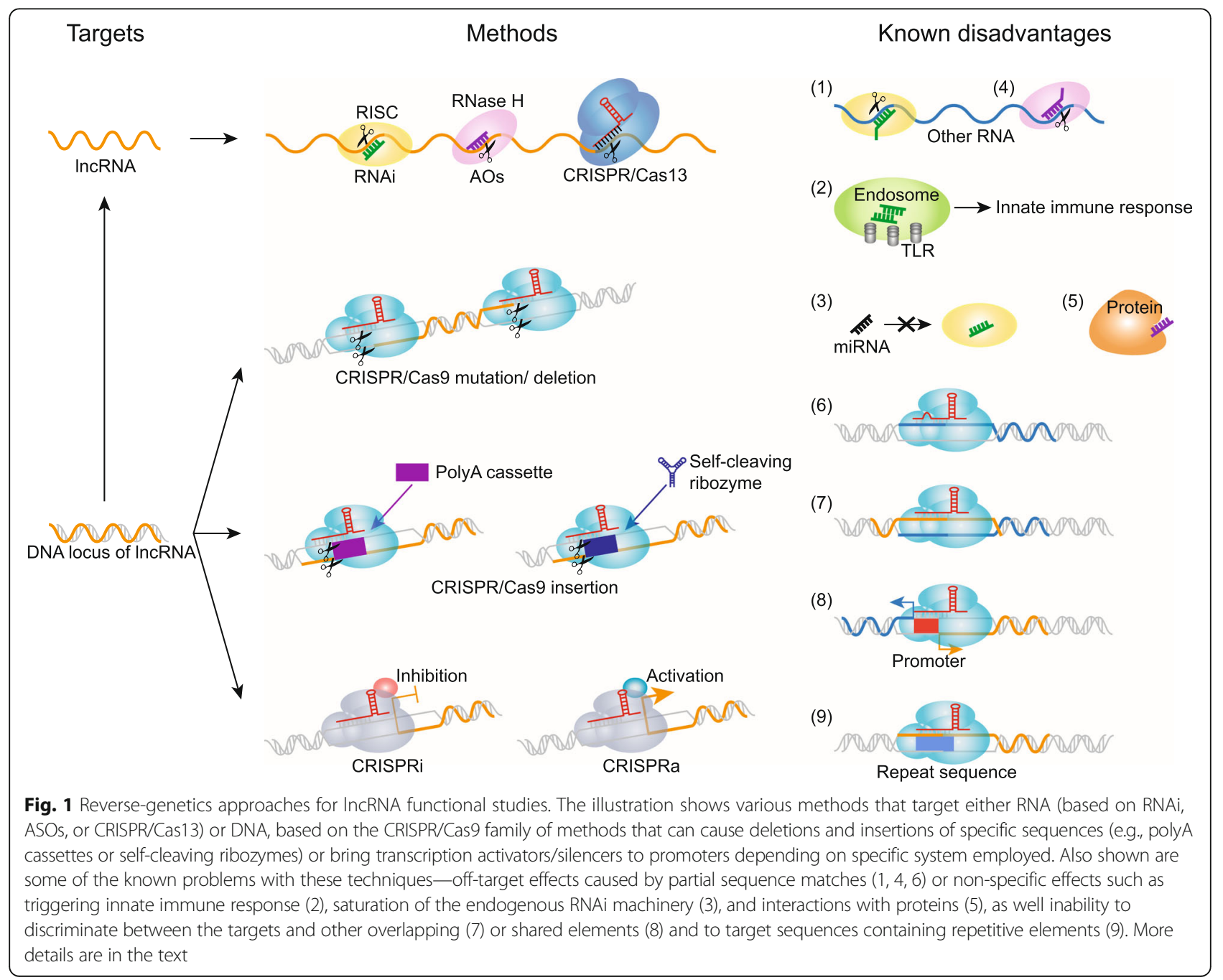


a cytosolic lncRNA SPRY4-IT1 has showed the role of this transcript in modulation of apoptosis [108]. Inhibition of a spliced lncRNA ARLNC1 localized in the nucleus and cytosol using either RNAi or ASO technologies has revealed its roles in androgen receptor signaling and growth of prostate cancer cells [109]. Knockdown of a spliced DGCR5 lncRNA that also localized in both cellular compartments using a mixture of siRNAs and ASOs has demonstrated involvement of this lncRNA in regulating a number of schizophrenia-related genes [110]. Overall, these techniques provided tremendous amount of support for functionality of various known types of lncRNAs. We estimate, based on the analysis of PubMed records, that applications of RNAi and ASO technologies have demonstrated functionality of lncRNAs in $>1500$ reports, with RNAi used in the vast majority of those studies. Annotation and functional characterization status of a particular lncRNA could be obtained by querying manually curated databases such as Lnc2Cancer [111], LncRNADisease [112], or LNCipedia [113]. An important note to RNAi- and ASO-based lncRNA functional studies is that most of them have been performed in cultured cells. Nonetheless, the vastness of the lncRNA universe for which the knockdown-associated phenotypes have been shown even led to discussions of potential clinical applications of lncRNA targeting based on these techniques [114].

\section{Genome targeting}

Evidence of lncRNA functionality has also come from other experimental strategies, most notably those that create a complete knockout by altering the DNA sequence of an lncRNA locus [115, 116] (Fig. 1). Application of the CRISPR/Cas9 genome-editing technology has provided support for biological functions of a number of lncRNAs, also predominantly in various cell line models at least in mammalian systems. Genome-editing approaches typically rely on deleting the whole lncRNA sequences or their regulatory regions, since subtle sequence changes require detailed knowledge of functional motifs and domains absent for most lncRNAs. In fact, successful targeted deletions have been achieved over a wide range of DNA sizes. For example, CRISPR/ Cas9-mediated hemizygous deletion of a relatively small ( $700 \mathrm{nt}$ ) lncRNA SPRIGHTLY (also known as SPRY4IT1) resulted in a decrease in anchorage-independent proliferation rate of cancer cells and the rate of tumor growth in a xenograft model [117]. On the other end of the spectrum, deletion of a 1.1-Mbp region on the human chromosome 6 containing a cluster of vlincRNAs in a fibrosarcoma cell line also using CRISPR/Cas9 has implicated one of them, vlinc273 or ASAR6-141, in control of replication timing of that chromosome [118]. In fact, IncRNA knockouts using genome-editing techniques in cultured cell models implicated lncRNAs in metabolism control $[119,120]$, cell growth $[119,121-$ 123], metastasis [124], and migration and invasion of human cancer cells $[119,122,123,125]$.

Furthermore, genome editing has also demonstrated functionality of lncRNAs in whole-animal in vivo studies in different animal models (Table 1). In mice, for example, knockout of the Charme lncRNA by CRISPR/ Cas9-mediated insertion of a polyA cassette into one of its exons resulted in homozygous mice with a specific heart remodeling phenotype (changes in size, structure, and shape of the organ) and reduced lifespan [71]. In nematode and fruit fly, systematic knockouts of multiple lncRNAs resulted in a significant fraction of the mutant animals exhibiting obvious phenotypes. Knockouts of 33 out of 105 testis-specific lncRNAs in fruit fly exhibited a partial or complete loss of male fertility [126]. Importantly, a number of the knockout phenotypes could be rescued by expression of the targeted lncRNAs, strongly arguing that loss of function of the corresponding transcripts caused the observed defects [126]. In Caenorhabditis elegans, knocking out 155 out of 170 annotated long intergenic RNAs (lincRNAs) could associate 23 of those with at least one of the 6 analyzed traits [127]. Just like in the previous example, the phenotypes could be either fully or partially rescued by ectopic expression of respectively 9 and 7 of the targeted transcripts [127]. More recently, knockouts of 10 out of 143 multi-exonic lncRNAs via CRISPR/Cas9-mediated deletions in the same species resulted in fertility or growth rate defects in 7 out of the 10 mutants [128]. Furthermore, loss of transcript as the cause of the phenotypes was shown by independent RNAi-mediated knockdowns for 2 out of the 6 tested loci [128].

Recent strategies based on targeting of transcriptional silencers or activators to specific promoters using the CRISPR/dead (d)Cas9 strategy (CRISPR interference (CRISPRi) or activation (CRISPRa)) have also contributed to phenotypic analyses of lncRNAs [129-132] (Fig. 1). For example, CRISPRi-mediated lncRNA knockdown revealed that a radial glia-specific lncRNA LOC646329 can regulate proliferation in human glioblastoma cells [129]. CRISPRa-mediated upregulation of 4 lncRNAs potentially involved in early cortical cell fate specifications confirmed their roles in regulating genes involved in this process [130].

\section{High-throughput screening}

The abovementioned approaches can also be scaled to a whole-genome level analysis in a population-like setting (Fig. 2). In such scenarios, each cell gets tagged or barcoded by an shRNA or a guide (g) RNA sequence targeting a specific transcript and stably integrated into the genome of the cell. Cells harboring tags against transcripts essential for survival would 
Table 1 In vivo phenotypic studies of IncRNAs

\begin{tabular}{|c|c|c|c|c|c|c|}
\hline IncRNA & Knockout strategy & In vivo phenotype & $\begin{array}{l}\text { RNA- } \\
\text { based rescue }\end{array}$ & $\begin{array}{l}\text { Phenotype } \\
\text { not attributed } \\
\text { to IncRNA }{ }^{2}\end{array}$ & $\begin{array}{l}\text { Knockout } \\
\text { technique }^{3}\end{array}$ & Reference \\
\hline H19 & $\begin{array}{l}\text { Replacement of a 3-kb gene region } \\
\text { and } 10 \mathrm{~kb} \text { of } 5^{\prime} \text { flanking sequence of } \\
\text { the IncRNA with a neomycin resistance } \\
\text { cassette }\end{array}$ & $\begin{array}{l}\text { Overgrowth in the animals inheriting } \\
\text { the } H 19 \text { mutation from their mothers } \\
\text { compared to those inheriting it from } \\
\text { their fathers }\end{array}$ & $\mathrm{N}$ & $\mathrm{Y}^{4}$ & $\mathrm{HR}$ & {$[32]$} \\
\hline H19 & $\begin{array}{l}\text { Replacement of the entire IncRNA } \\
\text { transcription unit with a neo cassette }\end{array}$ & Overgrowth (8\%) & $\mathrm{N}$ & $Y^{5}$ & $H R$ & [33] \\
\hline H19 & Same as above & $\begin{array}{l}\text { Overgrowth in the IncRNA knockouts } \\
\text { reflected in general (up to 20\%) } \\
\text { increase in weight. Corresponding } \\
\text { decrease in weight was observed in } \\
\text { knockout animals overexpressing the } \\
\text { IncRNA. }\end{array}$ & Y & & $\mathrm{HR}$ & [34] \\
\hline \multirow[t]{3}{*}{ H19 } & $\begin{array}{l}\text { Same as in Ripoche et al. [33]. The E6.5 } \\
\text { embryos were grafted into the wild- } \\
\text { type or Igf2 } 2^{--} \text {recipient mice to induce } \\
\text { teratocarcinomas. }\end{array}$ & $\begin{array}{l}\text { Increased weight of experimental } \\
\text { teratocarcinomas }\end{array}$ & $\mathrm{N}$ & & $\mathrm{HR}$ & [35] \\
\hline & $\begin{array}{l}\text { Knockout animals from Ripoche et al. } \\
\text { [33] were bred with } A p c^{\Delta 4 /+} \text { mice }\end{array}$ & $\begin{array}{l}\text { Increased number of adenomas } \\
\text { compared with their Apc littermates }\end{array}$ & $\mathrm{N}$ & & $\mathrm{HR}$ & \\
\hline & $\begin{array}{l}\text { Maternal heterozygotes of the H19 } \\
\text { knockout mice same as in Leighton } \\
\text { et al. [32] were bred with CRP-Tag 60-3 } \\
\text { male mice. }\end{array}$ & $\begin{array}{l}\text { Acceleration of liver tumor } \\
\text { development }\end{array}$ & $\mathrm{N}$ & & $\mathrm{HR}$ & \\
\hline H19 & Same as in Ripoche et al. [33] & $\begin{array}{l}\text { Muscle hypertrophy and hyperplasia. A } \\
50 \% \text { reduction in the number of } \\
\text { satellite cells }\end{array}$ & Y & & $H R$ & {$[36]$} \\
\hline H19 & Same as in Ripoche et al. [33] & $\begin{array}{l}\text { Increased tumor development after } \\
\text { carcinogen diethylnitrosamine } \\
\text { treatment }\end{array}$ & $\mathrm{N}$ & & $H R$ & {$[37]$} \\
\hline H19 & $\begin{array}{l}\text { Same as in Ripoche et al. [33]. The H19 } \\
\text { heterozygous male knockout mice } \\
\text { were bred with the wild-type mice to } \\
\text { generate paternal and maternal } \\
\text { knockouts. }\end{array}$ & $\begin{array}{l}\text { Increased liver weights immediately } \\
\text { after birth }\end{array}$ & $\mathrm{N}$ & & $\mathrm{HR}$ & {$[38]$} \\
\hline $\operatorname{rox} 1 / 2^{6}$ & $\begin{array}{l}\text { Deletion of the roX2 gene, transposon } \\
\text { insertion inactivation, or partial deletion } \\
\text { of the roX1 gene }\end{array}$ & $\begin{array}{l}\text { Male-specific reduction in viability in } \\
\text { the animals lacking both roX1 and roX2 } \\
\text { genes }\end{array}$ & Y & & & [39] \\
\hline Xist & $\begin{array}{l}\text { Replacement of most of the IncRNA } \\
\text { transcription unit with a neo cassette } \\
\text { while leaving the promoter intact }\end{array}$ & $\begin{array}{l}\text { Females carrying the Xist knockout on } \\
\text { the paternal chromosome exhibited } \\
\text { severe growth retardation and early } \\
\text { embryonic lethality. }\end{array}$ & $\mathrm{N}$ & & $\mathrm{HR}$ & {$[40]$} \\
\hline Xist & $\begin{array}{l}\text { Inversion of the exon } 1 \text { and deletion of } \\
\text { the exon } 4\end{array}$ & $\begin{array}{l}\text { Embryonic lethality in paternal } \\
\text { knockout mice }\end{array}$ & $\mathrm{N}$ & & $\begin{array}{l}\text { HR and } \\
\text { Cre }\end{array}$ & [41] \\
\hline Xist & $\begin{array}{l}\text { Mice with loxP sites inserted into Xist } \\
\text { intron } 3 \text { and } 5 \text { kb upstream of the } \\
\text { somatic cell promoter (Xist } 2 \text { lox/2lox) were } \\
\text { bred with Vav.Cre mice to conditionally } \\
\text { delete Xist in murine hematopoietic } \\
\text { stem cells. }\end{array}$ & $\begin{array}{l}\text { Females developed a highly aggressive } \\
\text { myeloproliferative neoplasm and } \\
\text { myelodysplastic syndrome with 100\% } \\
\text { penetrance. }\end{array}$ & $\mathrm{N}$ & & Cre & [42] \\
\hline Xist & $\begin{array}{l}\text { The Xist flffl or Xist }{ }^{\mathrm{Nl}} \text { mice generated } \\
\text { using the same knockout strategy as } \\
\text { above were crossed with Sox2-Cre mice } \\
\text { to conditionally delete Xist in the } \\
\text { epiblast lineage. }\end{array}$ & $\begin{array}{l}\text { Females exhibited retarded growth, } \\
\text { abnormal development of some } \\
\text { organs, and failure to survive past } \\
\text { weaning age. }\end{array}$ & $\mathrm{N}$ & & Cre & [43] \\
\hline Xist & Xist ${ }^{10 x}$ lox mice generated using the & Acceleration of primary tumor growth & $\mathrm{N}$ & & Cre & [44] \\
\hline
\end{tabular}
same knockout strategy as above were in mammary glands and metastases in crossed with MMTV-Cre mice to the brain generate animals with a mammaryspecific knockout of Xist. 
Table 1 In vivo phenotypic studies of IncRNAs (Continued)

\begin{tabular}{|c|c|c|c|c|c|c|}
\hline IncRNA & Knockout strategy & In vivo phenotype & $\begin{array}{l}\text { RNA- } \\
\text { based rescue }\end{array}$ & $\begin{array}{l}\text { Phenotype } \\
\text { not attributed } \\
\text { to IncRNA }{ }^{2}\end{array}$ & $\begin{array}{l}\text { Knockout } \\
\text { technique }^{3}\end{array}$ & Reference \\
\hline Malat1 & $\begin{array}{l}\text { Gene inactivation using insertion of the } \\
\text { lac } Z \text { gene and polyadenylation signals } \\
\text { immediately downstream of the } \\
\text { transcriptional start site }\end{array}$ & No apparent phenotype & N/A & & $H R$ & {$[25]$} \\
\hline Malat1 & 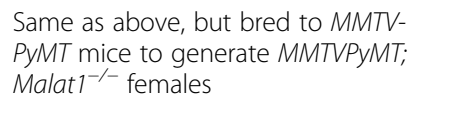 & $\begin{array}{l}\text { Promotion of lung metastasis in } \\
\text { the knockout animals with breast } \\
\text { cancer, contradictory to the results of } \\
\text { Arun et al. (2016) [47] }\end{array}$ & Y & & $H R$ & [45] \\
\hline Malat1 & $\begin{array}{l}\text { Deletion of a } \sim 3-k b \text { genomic region } \\
\text { containing the } 5^{\prime} \text { end of the Malat } \\
\text { gene and its promoter }\end{array}$ & No apparent phenotype & N/A & & $\begin{array}{l}\mathrm{HR}, \mathrm{FLP}, \\
\text { and Cre }\end{array}$ & {$[46]$} \\
\hline Malat1 & $\begin{array}{l}\text { Same as Zhang et al. [46], but bred } \\
\text { with MMTV-PyMT male mice }\end{array}$ & $\begin{array}{l}\text { Reduction of branching morphogenesis } \\
\text { in the MMTV-PyMT and Her } 2 / \text { heu- } \\
\text { amplified tumor organoids, increase of } \\
\text { cell adhesion, and loss of migration }\end{array}$ & N & & $\mathrm{HR}$ & [47] \\
\hline Malat1 & Same as Zhang et al. [46] & $\begin{array}{l}\text { Increased brain infarct size, worsened } \\
\text { neurological scores, and reduced } \\
\text { sensorimotor functions }\end{array}$ & N & & $H R$ & [48] \\
\hline Malat1 & $\begin{array}{l}\text { Deletion of the complete } 6982 \mathrm{bp} \\
\text { Malat } 1 \text { transcript sequence plus } 251 \mathrm{bp} \\
\text { upstream of the Malat transcription } \\
\text { start site and } 322 \text { bp downstream of } \\
\text { the Malat } 1 \text { transcript end }\end{array}$ & No apparent phenotype & N/A & & $\begin{array}{l}\text { HR and } \\
\text { Cre }\end{array}$ & [23] \\
\hline Malat1 & Same as above & No apparent phenotype & N/A & & $\begin{array}{l}\text { HR and } \\
\text { Cre }\end{array}$ & [24] \\
\hline Malat1 & $\begin{array}{l}\text { Same as in Eissmann et al. [23], but } \\
\text { crossed with Apoe }\end{array}$ & 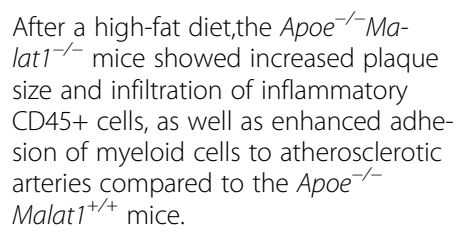 & $\mathrm{N}$ & & $\begin{array}{l}\text { HR and } \\
\text { Cre }\end{array}$ & [49] \\
\hline Hotair & Deletion of the exons 1 and 2 & $\begin{array}{l}\text { Three notable anatomical phenotypes } \\
\text { related to skeleton malformations }\end{array}$ & $\mathrm{N}$ & & $\begin{array}{l}\text { HR and } \\
\text { Cre }\end{array}$ & {$[50]$} \\
\hline Hotair & $\begin{array}{l}\text { The same knockout strain as above, } \\
\text { however, crossed into a different } \\
\text { genetic background }\end{array}$ & $\begin{array}{l}\text { No apparent phenotype attributable to } \\
\text { the IncRNA, failure to reproduce the } \\
\text { phenotypes above }\end{array}$ & $\mathrm{N} / \mathrm{A}$ & & $\begin{array}{l}\text { HR and } \\
\text { Cre }\end{array}$ & [26] \\
\hline Hotair & $\begin{array}{l}\text { Replacement of a } 2.3 \text {-kb genomic } \\
\text { sequence from exon } 1 \text { to the last } \\
\text { annotated exon with a lacz-neomycin } \\
\text { resistance cassette }\end{array}$ & $\begin{array}{l}\text { Morphological malformations in caudal } \\
\text { vertebra }\end{array}$ & N & & $H R$ & [51] \\
\hline Neat1 & $\begin{array}{l}\text { Gene inactivation using insertion of the } \\
\text { lac } Z \text { gene and polyadenylation signals } \\
\text { immediately downstream of the } \\
\text { transcriptional start site }\end{array}$ & $\begin{array}{l}\text { No apparent phenotypes except for } \\
\text { disappearance of paraspeckles }\end{array}$ & N/A & & $\mathrm{HR}$ & {$[52]$} \\
\hline Neat1 & Same as above & $\begin{array}{l}\text { Stochastic failure to become pregnant } \\
\text { in a subpopulation of the knockout } \\
\text { animals }\end{array}$ & N & & $\mathrm{HR}$ & {$[53]$} \\
\hline Neat1 & $\begin{array}{l}\text { Presumably the same as in Nakagawa } \\
\text { et al. [52] }\end{array}$ & $\begin{array}{l}\text { Aberrant mammary gland } \\
\text { morphogenesis and lactation defects }\end{array}$ & $\mathrm{N}$ & & & [54] \\
\hline Neat1 & Same as in Nakagawa et al. [52] & $\begin{array}{l}\text { Preneoplastic cells were sensitized to } \\
\text { DNA-damage-induced cell death, and } \\
\text { skin tumorigenesis was impaired. }\end{array}$ & $\mathrm{N}$ & & $H R$ & {$[55]$} \\
\hline Neat1 & Same as in Nakagawa et al. [52] & $\begin{array}{l}\text { Decrease of neointima formation } \\
\text { following vascular injury }\end{array}$ & $\mathrm{N}$ & & $\mathrm{HR}$ & {$[56]$} \\
\hline Neat1 & Deletion of the entire IncRNA & Reduction of inflammatory responses & $\mathrm{N}$ & & Cas9 & [57] \\
\hline
\end{tabular}


Table 1 In vivo phenotypic studies of IncRNAs (Continued)

\begin{tabular}{|c|c|c|c|c|c|c|}
\hline IncRNA & Knockout strategy & In vivo phenotype & $\begin{array}{l}\text { RNA- } \\
\text { based rescue }\end{array}$ & $\begin{array}{l}\text { Phenotype } \\
\text { not attributed } \\
\text { to IncRNA }\end{array}$ & $\begin{array}{l}\text { Knockout } \\
\text { technique }^{3}\end{array}$ & Reference \\
\hline Fendrr & $\begin{array}{l}\text { Replacement of exon } 1 \text { with a } \\
\text { transcriptional stop signal ( } 3 \times \mathrm{pA})\end{array}$ & $\begin{array}{l}\text { Embryonic lethality and impairment of } \\
\text { the heart and body wall }\end{array}$ & Y & & $H R$ & [58] \\
\hline Firre & $\begin{array}{l}\text { Deletion of the entire Firre gene body } \\
\text { and promoter }\end{array}$ & Cell-specific hematopoietic phenotypes & Y & & $\begin{array}{l}\text { HR and } \\
\text { Cre }\end{array}$ & [59] \\
\hline IncKdm2b & $\begin{array}{l}\text { Deletion of a 838-bp fragment contain- } \\
\text { ing the exon } 2\end{array}$ & $\begin{array}{l}\text { Impaired embryonic stem cell self- } \\
\text { renewal and early embryonic lethality }\end{array}$ & Y & & Cas9 & [60] \\
\hline PCFL & $\begin{array}{l}\text { Deletion of a } 6475 \text {-bp region contain- } \\
\text { ing PCFL and adjacent sequences }\end{array}$ & $\begin{array}{l}\text { Improved heart function and reduced } \\
\text { cardiac fibrosis after myocardial } \\
\text { infarction in heterozygous knockout } \\
\text { animals }\end{array}$ & Y & & Cas9 & [61] \\
\hline Chaer & Deletion of exon 2 & $\begin{array}{l}\text { Attenuated cardiac hypertrophy and } \\
\text { blunted pathological fibrosis following } \\
\text { trans-aortic constriction }\end{array}$ & $\begin{array}{l}\mathrm{N} \text { (in vitro } \\
\text { rescue only) }\end{array}$ & & Cas9 & [62] \\
\hline linc1405 & Deletion of exon 2 & $\begin{array}{l}\text { Impaired heart development and } \\
\text { function }\end{array}$ & $\begin{array}{l}\mathrm{N} \text { (in vitro } \\
\text { rescue only) }\end{array}$ & & Cas9 & [63] \\
\hline $\begin{array}{l}\text { lincRNA- } \\
\text { EPS }\end{array}$ & $\begin{array}{l}\text { Replacement of the entire 4-kb gen- } \\
\text { omic locus with a neomycin cassette }\end{array}$ & $\begin{array}{l}\text { Enhanced inflammation and lethality } \\
\text { following endotoxin challenge }\end{array}$ & $\begin{array}{l}\mathrm{N} \text { (in vitro } \\
\text { rescue only) }\end{array}$ & & $H R$ & [64] \\
\hline \multirow[t]{3}{*}{ IncKdm2b } & Same as in Ye et al. [60] & $\begin{array}{l}\text { Early embryonic lethality. Impaired } \\
\text { intestinal group } 3 \text { innate lymphoid cell } \\
\text { (ILC3) maintenance and proliferation }\end{array}$ & $\begin{array}{l}\mathrm{N} \text { (in vitro } \\
\text { rescue only) }\end{array}$ & & Cas9 & [65] \\
\hline & $\begin{array}{l}\text { Mice with loxP elements flanking the } \\
\text { exon } 2 \text { of IncKdm } 2 b \text { were crossed with } \\
\text { Vav-Cre } e^{+} \text {mice to generate animals with } \\
\text { a conditional deletion of IncKdm } 2 b \\
\text { from the bone marrow. }\end{array}$ & $\begin{array}{l}\text { Markedly decreased absolute numbers } \\
\text { of ILC3s }\end{array}$ & N & & $\begin{array}{l}\text { Cas9 and } \\
\text { Cre }\end{array}$ & \\
\hline & $\begin{array}{l}\text { Mice with loxP elements flanking the } \\
\text { exon } 2 \text { of IncKdm } 2 b \text { were crossed with } \\
\text { Rorc-Cre }{ }^{+} \text {mice to generate mice with } \\
\text { conditional deletion of IncKdm2b from } \\
\text { ILC3s. }\end{array}$ & $\begin{array}{l}\text { Remarkably decreased numbers of all } \\
\text { ILC3 subpopulations }\end{array}$ & N & & $\begin{array}{l}\text { Cas9 and } \\
\text { Cre }\end{array}$ & \\
\hline ANRIL & $\begin{array}{l}\text { Deletion of the } 70-\mathrm{kb} \text { region on } \mathrm{Chr} 4 \\
\text { containing the mouse gene aligning to } \\
\text { human } 58-\mathrm{kb} \text { non-coding CAD risk } \\
\text { interval }\end{array}$ & $\begin{array}{l}\text { Showed a protective effect on diabetic } \\
\text { mouse kidneys (lowering of urine } \\
\text { volume and urine albumin levels in } \\
\text { comparison with the wild-type diabetic } \\
\text { animals) }\end{array}$ & N & & $\begin{array}{l}\text { HR and } \\
\text { Cre }\end{array}$ & [66] \\
\hline Blncl & $\begin{array}{l}\text { Adipose tissue-specific deletion of the } \\
\text { entire gene }\end{array}$ & $\begin{array}{l}\text { Mice with fat-specific inactivation of } \\
\text { Blncl showed impaired cold-induced } \\
\text { thermogenesis and browning and ex- } \\
\text { acerbation of obesity-associated brown } \\
\text { fat whitening, adipose tissue inflamma- } \\
\text { tion, and fibrosis, leading to a more se- } \\
\text { vere insulin resistance and hepatic } \\
\text { steatosis. }\end{array}$ & N & & $\begin{array}{l}\text { Cas9 and } \\
\text { Cre }\end{array}$ & [67] \\
\hline \multirow[t]{2}{*}{ Blnc1 } & $\begin{array}{l}\text { Whole body deletion of the entire } \\
\text { gene }\end{array}$ & $\begin{array}{l}\text { Liver } X \text { receptor agonist-induced rise in } \\
\text { plasma triglyceride and hepatic steato- } \\
\text { sis was significantly blunted by Blncl } \\
\text { deficiency. }\end{array}$ & N & & Cas9 & [68] \\
\hline & $\begin{array}{l}\text { Liver-specific deletion of the entire } \\
\text { gene }\end{array}$ & $\begin{array}{l}\text { Abrogation of high-fat diet-induced } \\
\text { hepatic steatosis and insulin resistance } \\
\text { and prevention of diet-induced nonal- } \\
\text { coholic steatohepatitis }\end{array}$ & & & & \\
\hline Bmncr & $\begin{array}{l}\text { Deletion of the } 4.92-\mathrm{kb} \text { sequence of } \\
\text { Bmncr }\end{array}$ & $\begin{array}{l}\text { Decreased bone mass and increased } \\
\text { bone marrow adiposity }\end{array}$ & N & & $H R$ & [69] \\
\hline Blinc1 & 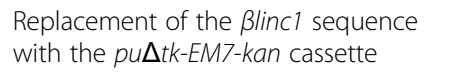 & $\begin{array}{l}\text { Defective islet development and } \\
\text { glucose-intolerance in the adult mice }\end{array}$ & N & & $H R$ & [70] \\
\hline Charme & $\begin{array}{l}\text { Insertion of a polyadenylation/MAZ } \\
\text { cassette into the beginning of the }\end{array}$ & $\begin{array}{l}\text { Peculiar heart remodeling phenotype } \\
\text { (changes in size, structure, and shape of }\end{array}$ & $\mathrm{N}$ & & $\begin{array}{l}\text { Cas9 and } \\
\text { HR }\end{array}$ & [71] \\
\hline
\end{tabular}


Table 1 In vivo phenotypic studies of IncRNAs (Continued)

\begin{tabular}{|c|c|c|c|c|c|c|}
\hline IncRNA & Knockout strategy & In vivo phenotype & $\begin{array}{l}\text { RNA- } \\
\text { based rescue }\end{array}$ & $\begin{array}{l}\text { Phenotype } \\
\text { not attributed } \\
\text { to IncRNA }\end{array}$ & $\begin{array}{l}\text { Knockout } \\
\text { technique }^{3}\end{array}$ & Reference \\
\hline & exon 2 & $\begin{array}{l}\text { the organ), morphological alteration of } \\
\text { skeletal and cardiac muscles, and } \\
\text { shortened lifespan }\end{array}$ & & & & \\
\hline$C P R$ & $\begin{array}{l}\text { Replacement of a 2968-bp fragment of } \\
\text { CPR gene containing exons } 1 \text { and } \\
2 \text { with a neo cassette }\end{array}$ & $\begin{array}{l}\text { Restored heart function after } \\
\text { myocardial injury (increased } \\
\text { cardiomyocyte proliferation, improved } \\
\text { myocardial function, and reduced scar } \\
\text { formation) }\end{array}$ & N & & $H R$ & [72] \\
\hline Cyrano & Deletion of the first half of the exon 3 & No overt abnormalities & N/A & & $\begin{array}{l}\mathrm{HR} \text { and } \\
\text { Cre }\end{array}$ & [27] \\
\hline \multirow[t]{2}{*}{ Dino } & $\begin{array}{l}\text { Replacement of the bulk of Dino } \\
\text { sequence with GFP }\end{array}$ & $\begin{array}{l}\text { Dampened } p 53 \text { signaling and } \\
\text { ameliorated acute radiation syndrome }\end{array}$ & $\mathrm{N}$ & & $H R$ & [73] \\
\hline & Inactivation of promoter & & & & & \\
\hline Evf2 & $\begin{array}{l}\text { Insertion of a triple polyadenylation } \\
\text { transcription stop site into the exon } 1\end{array}$ & $\begin{array}{l}\text { No apparent phenotype, except for } \\
\text { reduced numbers of GABAergic } \\
\text { interneurons in early postnatal } \\
\text { hippocampus and dentate gyrus }\end{array}$ & $\mathrm{N}$ & & $H R$ & [74] \\
\hline Fendrr & $\begin{array}{l}\text { Replacement with a lacZ reporter } \\
\text { cassette }\end{array}$ & $\begin{array}{l}\text { Perinatal lethal and lung, heart, and } \\
\text { gastrointestinal tract defects }\end{array}$ & $\mathrm{N}$ & & $H R$ & [75] \\
\hline Fendrr & $\begin{array}{l}\text { Replacement of a 19-kb genomic se- } \\
\text { quence from the exon } 2 \text { to the last an- } \\
\text { notated exon with a lacz-neomycin } \\
\text { resistance cassette }\end{array}$ & Perinatal lethal & N & & $H R$ & [51] \\
\hline \multirow[t]{2}{*}{ Flatr } & $\begin{array}{l}\text { Deletion of the promoter region and } \\
\text { the majority of the exon } 1\end{array}$ & No reported in vivo phenotype & $\mathrm{N}$ & & $\begin{array}{l}\text { Cas9 and } \\
\text { HR }\end{array}$ & [76] \\
\hline & Deletion of the entirety of the exon 2 & & & & Cas9 & \\
\hline Flicr & Deletion of the whole exon 2 & $\begin{array}{l}\text { Flicr-deficient non-obese diabetic fe- } \\
\text { male mice showed a significantly re- } \\
\text { duced rate and incidence of overt } \\
\text { diabetes. }\end{array}$ & $\mathrm{N}$ & & Cas9 & [77] \\
\hline Gm26878 & $\begin{array}{l}\text { A } 2.3-k b \text { deletion involving the entire } \\
\text { IncRNA-encoding gene }\end{array}$ & Neonatal lethal with low penetrance & N & & Cas9 & [78] \\
\hline Gomafu & $\begin{array}{l}\text { Deletion of the entire IncRNA gene } \\
(157 \mathrm{~kb})\end{array}$ & $\begin{array}{l}\text { Hyperactive behavior with increased } \\
\text { sensitivity to the psychostimulant } \\
\text { methamphetamine }\end{array}$ & N & & $\begin{array}{l}\mathrm{HR} \text { and } \\
\text { Cre }\end{array}$ & [79] \\
\hline Gt/2/Meg3 & $\begin{array}{l}\text { Replacement of the exons } 1-5(10 \mathrm{~kb}) \\
\text { with a neo cassette }\end{array}$ & $\begin{array}{l}\text { Maternal knockout pups died within } 4 \\
\text { weeks after birth. Paternal knockout } \\
\text { mice showed severe growth } \\
\text { retardation and perinatal lethality. } \\
\text { Homozygous mutants survived and } \\
\text { developed into fertile adults. }\end{array}$ & N & & $H R$ & [80] \\
\hline Gt12/Meg3 & $\begin{array}{l}\text { Replacement of the first five exons and } \\
\text { adjacent upstream promoter sequences } \\
\text { of } \sim 300 \mathrm{bp} \text { with a neo cassette }\end{array}$ & $\begin{array}{l}\text { Perinatal death and skeletal muscle } \\
\text { defects in the mice with the maternal } \\
\text { deletion }\end{array}$ & N & & $H R$ & [81] \\
\hline Gt12/Meg3 & Same as above & $\begin{array}{l}\text { Skeletal muscle defects and perinatal } \\
\text { death in the maternal } \\
\text { knockout animals, as well as increased } \\
\text { microvessel formation in the brain }\end{array}$ & N & & $H R$ & [82] \\
\hline Gt12/Meg3 & Same as above & $\begin{array}{l}\text { Increased microvessel formation in the } \\
\text { brain }\end{array}$ & N & & $H R$ & [83] \\
\hline Hottip & $\begin{array}{l}\text { Replacement of the } 4.8-\mathrm{kb} \text { genomic } \\
\text { sequence from the exon } 1 \text { to the last } \\
\text { annotated exon with a lacz-neomycin } \\
\text { resistance cassette }\end{array}$ & $\begin{array}{l}\text { Gastrocnemius muscle defects and } \\
\text { hindlimb skeletal malformation }\end{array}$ & N & & $H R$ & [51] \\
\hline Linc-Brn1b & $\begin{array}{l}\text { Replacement with a lacZ reporter } \\
\text { cassette }\end{array}$ & $\begin{array}{l}\text { Growth defects (reduced number of } \\
\text { intermediate progenitor cells in the }\end{array}$ & N & & $H R$ & {$[75]$} \\
\hline
\end{tabular}


Table 1 In vivo phenotypic studies of IncRNAs (Continued)

\begin{tabular}{|c|c|c|c|c|c|c|}
\hline IncRNA & Knockout strategy & In vivo phenotype & $\begin{array}{l}\text { RNA- } \\
\text { based rescue }\end{array}$ & $\begin{array}{l}\text { Phenotype } \\
\text { not attributed } \\
\text { to IncRNA }{ }^{2}\end{array}$ & $\begin{array}{l}\text { Knockout } \\
\text { technique }^{3}\end{array}$ & Reference \\
\hline & & $\begin{array}{l}\text { cerebral cortex, abnormal cortical } \\
\text { lamination and disorganization of the } \\
\text { barrel cortex, reduced body weight) }\end{array}$ & & & & \\
\hline Linc-pint & $\begin{array}{l}\text { Replacement with a lacZ reporter } \\
\text { cassette }\end{array}$ & $\begin{array}{l}\text { Growth defects (noticeably smaller and } \\
\text { reduced body weight) }\end{array}$ & $N$ & & $\mathrm{HR}$ & {$[75]$} \\
\hline Linc-pint & $\begin{array}{l}\text { Replacement of the } 32-\mathrm{kb} \text { genomic se- } \\
\text { quence from the exon } 2 \text { to the last an- } \\
\text { notated exon with a lacz-neomycin } \\
\text { resistance cassette }\end{array}$ & $\begin{array}{l}\text { Growth deficiency (slower growth rate, } \\
\text { age-dependent abnormal hindlimb } \\
\text { clasping posture, fur loss, lower fat con- } \\
\text { tent and femur bone mineral density, } \\
\text { decreased muscle mass, and } \\
\text { lordokyphosis) }\end{array}$ & $N$ & & $\mathrm{HR}$ & {$[51]$} \\
\hline Linc-RAM & Deletion of the exon 2 & Delayed muscle regeneration & $N$ & & $\begin{array}{l}\text { HR and } \\
\text { Cre }\end{array}$ & [84] \\
\hline $\begin{array}{l}\text { lincRNA- } \\
\text { p21 }\end{array}$ & $\begin{array}{l}\text { Mice with loxP sites flanking the } p 53 \\
\text { response element in the promoter and } \\
\text { exon } 1 \text { of the IncRNA were crossed } \\
\text { with the Deletor Cre mice to achieve } \\
\text { a conditional knockout. }\end{array}$ & No significant abnormalities & N/A & & $\begin{array}{l}\text { HR, FLP } \\
\text { and Cre }\end{array}$ & {$[28]$} \\
\hline LnCDACH1 & $\begin{array}{l}\mathrm{LnCDACH} 1^{\text {Flox/Flox }} \text { mice were crossed } \\
\text { with a-myosin heavy chain Cre mice to } \\
\text { generate mice with a cardiac myocyte- } \\
\text { specific knockout of } \mathrm{LnCDACH} \text {. }\end{array}$ & $\begin{array}{l}\text { Increased calcium transient, cell } \\
\text { shortening, and improved cardiac } \\
\text { function of transverse aortic } \\
\text { constriction induced heart failure mice. }\end{array}$ & $N$ & & $\begin{array}{l}\text { Cas9 and } \\
\text { Cre }\end{array}$ & {$[85]$} \\
\hline \multirow[t]{4}{*}{ IncGata6 } & $\begin{array}{l}\text { Deletion of the region from the exon } 2 \\
\text { to the exon } 4\end{array}$ & $\begin{array}{l}\text { Impaired stemness of intestinal stem } \\
\text { cells (ISCs) and intestinal regeneration }\end{array}$ & $N$ & & Cas9 & {$[86]$} \\
\hline & $\begin{array}{l}\text { Insertion of an SV } 40 \text { poly(A) (STOP) } \\
\text { module into the promoter of } \\
\text { the IncRNA }\end{array}$ & Same as above & & & & \\
\hline & Mutation in the IncRNA exon 4 & Same as above & & & & \\
\hline & $\begin{array}{l}\text { Insertion of loxP sequences flanking the } \\
\text { exons } 2-4 \text { of the IncGata6 locus and } \\
\text { establishing Lgr5 } 5^{G F P-C r e E R T 2} ; \text { Rosa26 } 6^{\mid l-l a c z} \\
\text { IncGata6 } 6^{f / f} \text { mice }\end{array}$ & $\begin{array}{l}\text { Reduction of ISCs with suppressed } \\
\text { cycling and proliferation of ISCs } \\
\text { compared to Lgr5 } 5^{G F P-C r e E R T 2} ; \text { Rosa26 } 6^{I s-l a c z} \\
\text { mice }\end{array}$ & & & $\begin{array}{l}\text { Cas9 and } \\
\text { Cre }\end{array}$ & \\
\hline Lnc-mg & $\begin{array}{l}\text { Conditional deletion of the exon } 1 \text { in } \\
\text { the muscle }\end{array}$ & $\begin{array}{l}\text { Muscle atrophy and the loss of } \\
\text { muscular endurance during exercise }\end{array}$ & $N$ & & $\begin{array}{l}\text { HR and } \\
\text { Cre }\end{array}$ & {$[87]$} \\
\hline $\operatorname{lncOb}$ & $\begin{array}{l}\text { Deletion of the } 5^{\prime} \text { end of the IncRNA } \\
\text { first exon }\end{array}$ & $\begin{array}{l}\text { Increased fat mass with reduced } \\
\text { plasma leptin levels and lost weight } \\
\text { after a leptin treatment }\end{array}$ & $N$ & & Cas9 & {$[88]$} \\
\hline $\begin{array}{l}\text { InCRNA- } \\
155\end{array}$ & $\begin{array}{l}\text { Deletion of most of the IncRNA } \\
\text { sequence }\end{array}$ & $\begin{array}{l}\text { Increased susceptibility to influenza A } \\
\text { virus infection }\end{array}$ & $N$ & & $\mathrm{HR}$ & {$[89]$} \\
\hline Mdgt & $\begin{array}{l}\text { Replacement with a lacZ reporter } \\
\text { cassette }\end{array}$ & Reduced viability and growth & $\mathrm{N}$ & & $\mathrm{HR}$ & [75] \\
\hline PEAT & $\begin{array}{l}\text { Deletion of the entire IncRNA } \\
\text { transcribed unit }\end{array}$ & No apparent phenotype & N/A & & Cas9 & [29] \\
\hline Peril & $\begin{array}{l}\text { Replacement with a lacZ reporter } \\
\text { cassette }\end{array}$ & $\begin{array}{l}\text { Reduction of viability, death shortly } \\
\text { after birth as well as reduced body } \\
\text { weight }\end{array}$ & $N$ & & $H R$ & {$[75]$} \\
\hline Redrum & Deletion of the IncRNA exon 3 & No apparent phenotype & N/A & & $\begin{array}{l}\text { Cas9 and } \\
\text { HR }\end{array}$ & {$[30]$} \\
\hline $\begin{array}{l}\text { Rik-201 } \\
\text { and Rik- } \\
203\end{array}$ & $\begin{array}{l}\text { Deletion from the beginning of second } \\
\text { exon to the end of the third exon of } \\
\text { the InCRNA C130071C03Rik }\end{array}$ & Abnormal brain development & $N$ & & Cas9 & [90] \\
\hline Silc1 & $\begin{array}{l}\text { Deletion of the IncRNA promoter and } \\
\text { exon } 1\end{array}$ & $\begin{array}{l}\text { Delayed regeneration of sensory } \\
\text { neurons following injury }\end{array}$ & N & & Cas9 & [91] \\
\hline SRA & Insertion of a lacZ/neo cassette with & Obesity resistance and improved & $\mathrm{N}$ & & $\mathrm{HR}$ & [92] \\
\hline
\end{tabular}
transcription termination signals before glucose tolerance in knockout mice fed the exon 3

a high-fat diet 
Table 1 In vivo phenotypic studies of IncRNAs (Continued)

\begin{tabular}{|c|c|c|c|c|c|c|}
\hline IncRNA & Knockout strategy & In vivo phenotype & $\begin{array}{l}\text { RNA- } \\
\text { based rescue }\end{array}$ & $\begin{array}{l}\text { Phenotype } \\
\text { not attributed } \\
\text { to } \operatorname{lncRNA^{2}}\end{array}$ & $\begin{array}{l}\text { Knockout } \\
\text { technique }^{3}\end{array}$ & Reference \\
\hline SYISL & $\begin{array}{l}\text { Deletion of a 1133-bp genomic region } \\
\text { containing most of the SYISL transcript }\end{array}$ & $\begin{array}{l}\text { Increased muscle fiber density, muscle } \\
\text { mass, and regeneration }\end{array}$ & N & & Cas9 & [93] \\
\hline Tsix & $\begin{array}{l}\text { Deletion of a } 3.7-\mathrm{kb} \text { CpG-rich domain } \\
\text { at the } 5^{\prime} \text { end of Tsix that included the } \\
\text { putative promoter and transcriptional } \\
\text { start site }\end{array}$ & $\begin{array}{l}\text { The knockout mice showed normal } \\
\text { paternal but impaired maternal } \\
\text { transmission. Maternal inheritance is } \\
\text { infrequent, with surviving progeny } \\
\text { showing intrauterine growth } \\
\text { retardation and reduced fertility. }\end{array}$ & $\mathrm{N}$ & & $H R$ & [94] \\
\hline Tsix & $\begin{array}{l}\text { Insertion of an IRES } \beta g e o \text { cassette in the } \\
\text { second exon to disrupted IncRNA } \\
\text { transcripts from both promoters }\end{array}$ & $\begin{array}{l}\text { Inheritance of the disrupted maternal } \\
\text { allele resulted in ectopic Xist expression } \\
\text { and early embryonic lethality }\end{array}$ & N & & $H R$ & [95] \\
\hline Tslrn1 & $\begin{array}{l}\text { Deletion of the entire IncRNA } \\
\text { transcribed region }\end{array}$ & $\begin{array}{l}\text { Male knockout mice displayed normal } \\
\text { fertility but a significant reduction in } \\
\text { spermatozoa. }\end{array}$ & N & & Cas9 & [96] \\
\hline Ts $x$ & $\begin{array}{l}\text { Deletion of a } 2.1-\mathrm{kb} \text { region } \\
\text { encompassing the predicted promoter } \\
\text { region, exon } 1 \text {, and } 160 \mathrm{bp} \text { of intron } 1\end{array}$ & $\begin{array}{l}\text { Male mutant animals have smaller } \\
\text { testes and altered behavior with less } \\
\text { fear and enhanced short-term memory. }\end{array}$ & $\mathrm{N}$ & & $\begin{array}{l}\text { HR, FLP } \\
\text { and Cre }\end{array}$ & [97] \\
\hline Visc- -2 & Deletion of the entire IncRNA locus & $\begin{array}{l}\text { No overt anatomical or behavioral } \\
\text { phenotype }\end{array}$ & N/A & & $H R$ & {$[31]$} \\
\hline Air/Airn & $\begin{array}{l}\text { Insertion of a polyadenylation cassette } \\
\text { to truncate Air to } 4 \% \text { of its length }\end{array}$ & $\begin{array}{l}\text { Mice with the maternally inherited } \\
\text { mutant allele were identical to the wild } \\
\text { type. Animals with the paternally } \\
\text { inherited mutant allele or homozygous } \\
\text { mutant mice showed a } 15 \% \text { reduction } \\
\text { in birth weight. }\end{array}$ & N & $Y^{7}$ & $\begin{array}{l}\text { HR and } \\
\text { Cre }\end{array}$ & [98] \\
\hline Crnde & Ablation of the whole coding region & $\begin{array}{l}\text { Low bone mass phenotype due to } \\
\text { impaired osteoblast proliferation and } \\
\text { differentiation }\end{array}$ & $\begin{array}{l}N \text { (in vitro } \\
\text { rescue only) }\end{array}$ & Possible $^{8}$ & Cas9 & [99] \\
\hline \multirow{2}{*}{$\begin{array}{l}\text { Hand2as/ } \\
\text { Hand2os1/ } \\
\text { IncHand2/ } \\
\text { Uph }\end{array}$} & Deletion of the exon 1 and/or exon 2 & $\begin{array}{l}\text { Liver damage and liver regeneration } \\
\text { defects }\end{array}$ & Y & & Cas9 & {$[100]$} \\
\hline & $\begin{array}{l}\text { Conditional deletion of the exon } 2 \text { in } \\
\text { hepatocytes }\end{array}$ & $\begin{array}{l}\text { Severe liver injury, much poorer liver } \\
\text { regeneration capacity, and a smaller } \\
\text { liver mass }\end{array}$ & $\mathrm{N}$ & & $\begin{array}{l}\text { Cas9 and } \\
\text { Cre }\end{array}$ & \\
\hline $\begin{array}{l}\text { Hand2as/ } \\
\text { Hand2os1/ } \\
\text { IncHand2/ } \\
\text { Uph }\end{array}$ & $\begin{array}{l}\text { Insertion of a triple polyadenylation } \\
\text { sequence into the exon } 2\end{array}$ & $\begin{array}{l}\text { Right ventricular hypoplasia and } \\
\text { embryonic lethality }\end{array}$ & $\mathrm{N}$ & $Y^{9}$ & TALENS & [101] \\
\hline \multirow{3}{*}{$\begin{array}{l}\text { Hand2as/ } \\
\text { Hand2os1/ } \\
\text { IncHand2I } \\
\text { Uph }\end{array}$} & Deletion of the entire IncRNA locus & $\begin{array}{l}\text { Septum lesion, heart hypoplasia, and } \\
\text { perinatal death }\end{array}$ & \multirow[t]{3}{*}{ N } & \multirow[t]{3}{*}{$Y^{10}$} & \multirow[t]{3}{*}{ Cas9 } & \multirow[t]{3}{*}[21]{} \\
\hline & $\begin{array}{l}\text { Deletion of a } 2.7-\mathrm{kb} \text { DNA sequence } \\
\text { that spans exons } 4 \text { and } 5\end{array}$ & $\begin{array}{l}\text { Severe contraction defects in adult } \\
\text { heart that progressively worsened with } \\
\text { increasing age }\end{array}$ & & & & \\
\hline & $\begin{array}{l}\text { Deletion of the } 5 \text { ' promoter and first } \\
\text { two exons }\end{array}$ & $\begin{array}{l}\text { No discernable heart phenotypes in } \\
\text { either embryos or adults }\end{array}$ & & & & \\
\hline
\end{tabular}

\footnotetext{
${ }^{1} Y$ yes, $N$ no, $N / A$ not applicable

${ }^{2} Y$ yes

${ }^{3} \mathrm{HR}$ homologous recombination, Cre Cre-mediated recombination, Cas9 CRISPR/Cas9, FLP FLP-mediated recombination

${ }^{4}$ The phenotype of the $\mathrm{H} 19$ knockout mice was attributed to a gain of function of Igf2 due to the loss of a common imprinting control element caused by the $\mathrm{H} 19$ deletion instead of the deletion of the $\mathrm{H} 19$ gene itself

${ }^{5}$ The phenotype was also attributed to the increase in the lgf2 expression via deletion of a shared imprinting control element mapped to a $10-\mathrm{kb}$ region upstream of $\mathrm{H} 19$

${ }^{6}$ All studies were done in mouse with the exception of the roX genes done in Drosophila melanogaster

${ }^{7}$ Latos et al. [102] (see the text) reported that Airn transcriptional overlap, but not its IncRNA products, induces imprinted lgf2r silencing

${ }^{8}$ Szafron et al. [103] (see the text) showed that CRNDE encodes a nuclear peptide (CRNDEP) which may be involved in the regulation of the cell proliferation

${ }^{9}$ The phenotype was caused by blockade of the IncRNA transcription, but not the knockdown of the mature transcript

${ }^{10}$ The DNA locus, rather than its transcription/transcripts, was shown to be primarily responsible for the heart development and function phenotypes
} 


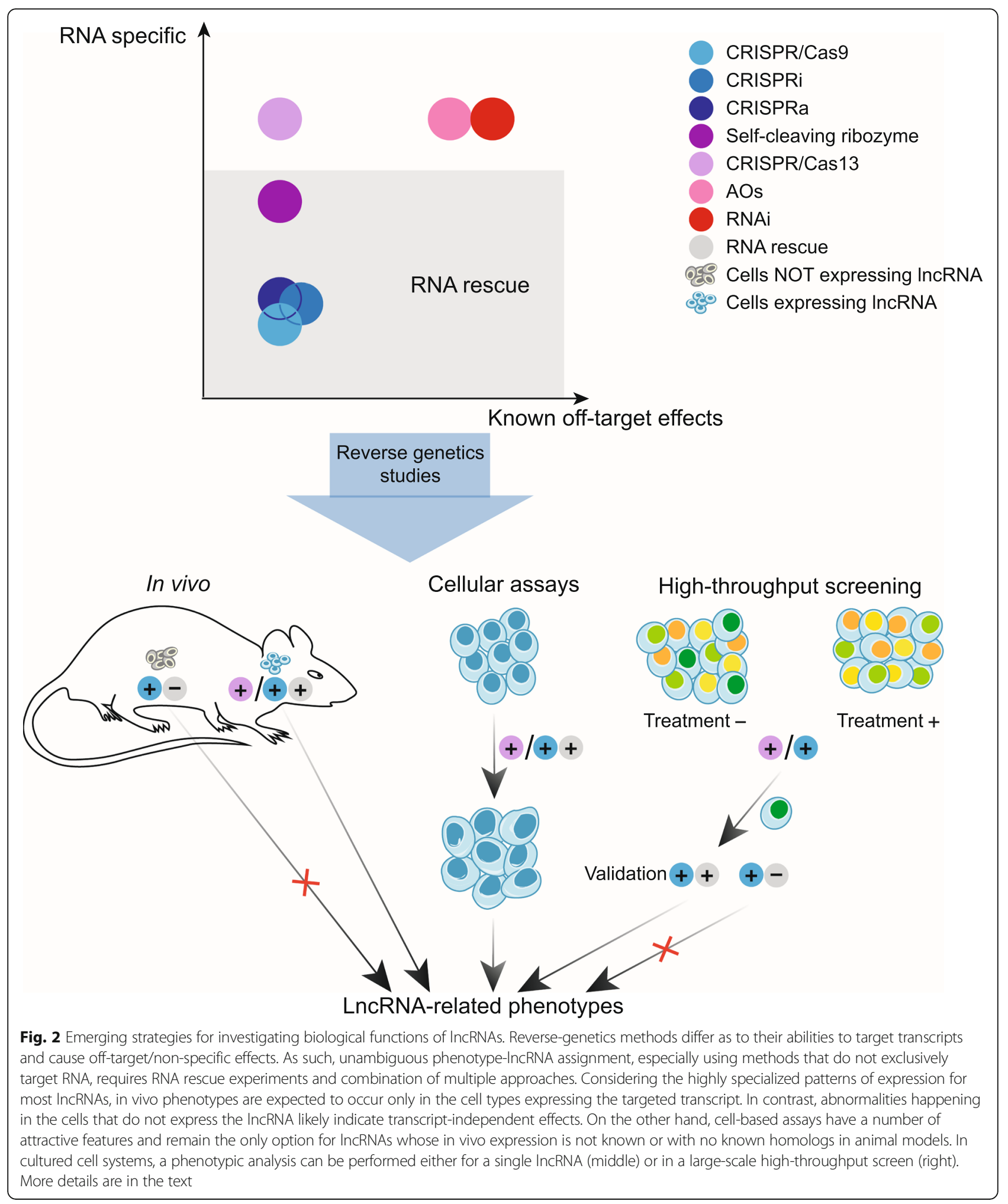

have a tendency to get lost from the population and this loss can be measured by high-throughput sequencing of the barcodes. Such global screens based on the shRNA, CRISPR/Cas9, and CRISPR/dCas9 approaches have also been applied to lncRNA functional studies [133-137].

Importantly, each such survey could identify functional lncRNAs, even though these studies differed in terms of 
the numbers of targeted transcripts and apparent fraction of phenotypically relevant lncRNAs, thus resulting in very different numbers of the reported functional lncRNAs. For example, using stringent selection criteria, a study with shRNA library targeting 3842 lncRNAs and ultraconserved genomic elements identified one lncRNA Ntep as an essential regulator of cell proliferation in NIH3T3 fibroblasts [133]. A dual coding and non-coding integrated CRISPRa screen using 70,290 single guide (sg) RNAs targeting all human RefSeq coding isoforms and 88,444 sgRNAs targeting 14,701 lncRNA genes found the GAS6AS2 IncRNA that acts in a cis- and trans-manner to regulate GAS6/AXL signaling [134]. On the other hand, an shRNA library screen targeting 1280 lincRNAs in the mouse genome identified 20 , or $1.6 \%$ of these lincRNAs, involved in pluripotency maintenance [135]. Furthermore, a CRISPR/Cas9-mediated genome-scale deletion study of 700 human lncRNAs identified 51 (7.3\%) of them as positive or negative regulators of human cancer cell growth [136]. A CRISPRi-based screen targeting 16,401 lncRNA loci in 6 human transformed cell lines and 1 induced pluripotent stem cell (iPSC) identified 499 or 3\% of the IncRNA loci required for robust cellular growth [137]. Interestingly, this study also provided a potential reason for the different efficiencies of such surveys: $89 \%$ of the functionally relevant lncRNAs showed growth modifying function exclusively in one cell type, indicating a celltype-specific mode of functioning for many lncRNAs [137]. This finding underscores the need for properly choosing biological systems for lncRNA reverse-genetics studies (also see below). Nonetheless, every reported whole-genome survey could identify at least one lncRNA functionally relevant for the biological system employed.

\section{Evolutionary conservation}

Contribution of a genomic element to survival of a species or species over multiple generations in real-life field conditions arguably represents the ultimate test of functional significance of that genomic feature. While such experiments are very challenging to conduct in vivo for practical reasons (also see below), the availability of genome sequences for a multitude of species allows to estimate the ability of a genomic element to withstand natural processes of sequence change or loss during evolution. In other words, the genome of any given species (or individual) contains information on a myriad of past survival experiments conducted over millions of years of evolution and comparison of multiple genomes among or within multiple species allows to extract it. Any genomic sequence that changes less than expected from random chance (or, in other words, remains conserved) across genomes of multiple species is widely assumed to represent a genomic feature that contributes to survival even if the function of the latter is unknown. And, indeed, such assumption has been exhaustively validated on exons of protein-coding genes where the general trend of primary sequences conservation across multiple species is very obvious.

In contrast, with notable exceptions of some highly conserved lncRNAs such as Neat1 and Malat1 [46], in general, primary sequences of mammalian lncRNAs do not exhibit features consistent with evolutionary conservation [138]. Such studies have some important caveats, however, as reviewed by Pang et al. [139]. Of special note, IncRNA evolutionary conservation signatures can become apparent when features other than primary sequences are compared, specifically RNA 2D structures [140], transcript exon-intron structures [141], relative positions in the genomes (synteny), and expression patterns [142]. Specifically, conservation of an exon-intron structure implies selective pressure on the transcript rather than DNA sequence elements that might overlap it [141]. Strikingly, using this approach, Nitsche et al. revealed conservation of over $70 \%$ of 5413 human lncRNAs across major eutherian families [141]. Furthermore, Hezroni et al. estimated that over 1000 human lincRNAs have conserved functions in mammals based on conservation of synteny and expression patterns across 17 species [142].

\section{IncRNAs appear to be dispensable for a vertebrate organism}

Despite the ample body of evidence supporting general biological relevance of the lncRNA class of transcripts reviewed above, derived primarily from studies on cultured cells, multiple in vivo reverse-genetics probes into their function done in vertebrate organisms challenge this conclusion. The first indication that the non-coding genome is dispensable for their survival came in 2004 when Nobrega et al. reported on strains of mice engineered to have deletions of two large non-coding gene desert regions, $1511 \mathrm{~kb}$ and $845 \mathrm{~kb}$ in lengths, harboring 1243 non-coding sequences conserved between humans and rodents [143]. Mice homozygous for the deletions had no distinguishable changes in multiple general homeostasis criteria [143]. While the presence of lncRNAs in the deleted regions was not assessed, considering that based on the ENCODE consortium's estimates, up to $75 \%$ of the human genome is transcribed [3], it is highly likely the large deleted regions do in fact encode such transcripts.

Recently, Han et al. knocked out 12 lncRNAs from the mouse genome, including 9 lncRNAs conserved syntenically in the human genome, 8 located near developmentally important genes, and 4 previously reported to play important biological roles based on studies in cultured cells [21]. Despite the fact that the selection of the targets was supposed to enrich for developmentally 
important lncRNAs, the authors found that mice homozygous for knockouts of 11 out of the 12 lncRNAs were born at the expected Mendelian ratios and were viable with no obvious abnormalities [21]. The phenotype of the remaining lncRNA knockout was attributed to the deletion of a DNA sequence, rather than the transcript itself (see below) [21]. In 2019, Goudarzi et al. used the CRISPR/Cas9 approach to knockout 25 zebrafish IncRNAs [22]. Just like in the study above, the authors have carefully selected these transcripts based on conservation, expression patterns, and proximity to genes important in development to maximize the possibility of biological relevance of these lncRNAs [22]. Strikingly, although some might affect transcription of neighboring genes, none of the $25 \operatorname{lncRNAs}$ were required for embryogenesis, viability, or fertility [22].

In addition to the failure of generating in vivo phenotypes, reproducing those that could be obtained appears less than certain (Table 1). Perhaps the most striking example of this concerns one of the most studied lncRNAs, Hotair, whose biological significance recently became a subject of debate $[26,50,144,145]$. In 2013, Howard Chang's lab reported that a targeted homozygous deletion of Hotair in the mouse genome led to homeotic transformation, derepression of genes including HoxDs, and skeletal malformations [50]. However, in 2016, Denis Duboule's lab obtained the Hotair deletion strain of mice from the Chang's team and crossed it with animals of a different background [26]. They found no detectable change in the HoxD gene expression and no significant morphological alterations in the progeny harboring the homozygous deletion of the lncRNA [26]. Overall, of the 3 anatomical phenotypes associated with the Hotair knockout reported by the Chang's group, 2 could not be found by the Duboule's team at all and one was found in a very subtle form and attributed to DNA-dependent events [26]. Furthermore, the Duboule's team could not reproduce any of the previously reported effects of the Hotair knockout on gene expression [26]. In another example, the Gomafu lncRNA was associated with an anxiety-like behavior in mice where this transcript was knocked down in the medial prefrontal cortex using ASOs [146]. However, a later study in knockout mice lacking Gomafu in the entire brain showed no difference in the same behavioral tests [79].

To further compound the problem with in vivo phenotypes, those initially believed to associate with lncRNAs can actually be caused by different mechanisms. For example, the Linc- $p 21$ lncRNA has been extensively studied due to its involvement in p53 signaling, human diseases and has been reported to regulate various biological processes [28, 147-149]. It may function in cis [28] or trans [147]. However, an in vivo study using a mouse knockout model showed that deletion of the locus significantly affected local gene expression even in tissues with no detectable Linc-p21 expression, suggesting that DNA enhancer elements in the Linc-p21 locus rather than the transcript itself are responsible for this effect [150]. In another example, mice engineered to have insertion of a polyA cassette into the Hand2as lncRNA showed right ventricular hypoplasia and embryonic lethality phenotypes, thus associating this transcript with heart development [101]. However, a later study that created separate deletions of the Hand2as gene body and promoter regions with the CRISPR/Cas9 technology found only the former to have heart-related defects, thus arguing that the phenotypes were caused by the DNA locus rather than the IncRNA [21].

Even for the lncRNAs generally considered as the "gold standards," the situation with the strength of evidence for their in vivo functionality is not straightforward (Table 1). Xist, H19, roX, Neat1, Malat1, and Hotair are perhaps the most well-studied lncRNAs accounting for at least 4500 records in PubMed. For example, in the case of Malat1, a number of studies using cultured cells associated this lncRNA with the regulation of gene expression [151] and a variety of biological processes like pre-mRNA splicing, cancer cell metastasis, cell cycle progression, and serum-induced cell proliferation [152155]. However, in 2012, Eissmann et al. [23], Nakagawa et al. [25], and Zhang et al. [46] independently generated Malat1 knockout mice and found the homozygous knockouts to be viable and fertile, with no obvious phenotypes or histological abnormalities, including no obvious defects in nuclear speckles where this lncRNA localizes. Furthermore, despite significant evidence of involvement of Malat1 in hypoxia response and specifically in renal ischemia-reperfusion injury, no discernable in vivo effect of the IncRNA on that condition was observed in a mouse knockout [24]. On the other hand, in vivo effect of Malat1 in brain tissues after ischemic stroke could be observed; however, no RNA rescue experiments have been conducted in those studies [48] (also see below for additional discussion of Malat1 in vivo studies). In summary, strikingly, even among those transcripts, clear and uncontroversial evidence of biological function in vivo exists only for very few (Table 1). In fact, among the "gold standard" lncRNAs mentioned above, consistent in vivo phenotypes that could be restored in RNA rescue experiments thus unequivocally attributing the phenotypes to the corresponding transcripts were only reported for roX and H19 (Table 1).

All in all, the points discussed above clearly show that a very large gap exists between the abundance of data demonstrating biological function of lncRNAs in cultured cells and the difficulty in obtaining such evidence 
in in vivo studies. Below, we will try to provide reasons, both technical and biological, that might explain this discrepancy and try to reconcile potential biological functionality of the lncRNA class of transcripts with these observations.

\section{Targeted IncRNA is not always the cause of the phenotype attributed to it \\ Non-specific or off-target effects in reverse-genetics assays}

The most trivial explanation for the discrepancies described above is that phenotypes observed after IncRNA knockdowns or knockouts are not related to these transcripts. Indeed, a number of recent reports suggest that this is a likely possibility. As mentioned above, RNA depletion strategies using RNAi or ASOs account for majority of the phenotypic evidence. Most often, such studies are done by transfecting synthetic siRNA or ASO molecules into cultured cells. However, this can lead to supraphysiological amounts of the synthetic molecules inside the cells leading to formation of aberrant RNA species that can cause non-specific changes in gene expression [156] and potentially cause phenotypic changes unrelated to the intended targets. Furthermore, both RNAi and ASOs have well-recognized non-specific and off-target effects [157-165] that are very hard or even impossible to completely avoid and non-trivial to control for $[162,166]$. For example, a recent report by Stojic et al. found that transfection of non-specific siRNAs or ASOs can cause substantial transcriptome changes in a sequence-specific manner [162]. This observation has huge practical implications since vast majority of siRNA/ ASO studies use a single control of unrelated or scrambled sequence to estimate non-specific effects of the targeting siRNAs/ASOs.

These results imply that RNAi- and ASO-based studies potentially have non-specific effects unaccounted for and, logically, these effects could in fact be responsible for the observed phenotypes. Indeed, this has been shown to be the case. Goudarzi et al. injected morpholino antisense oligonucleotides (MOs) against the lncRNA cyrano into homozygous zebrafish deletion mutant lines with no corresponding target sequences for that lncRNA present [22]. Strikingly, they could reproduce all phenotypes previously reported based on injection of the same MOs into wild-type animals, suggesting that the phenotypes were caused by non-specific effects of the MOs rather than by the knockdown of the IncRNA [22]. Furthermore, Kok et al. generated a zebrafish mutant with a segment of the IncRNA megamind targeted by previously published MOs deleted [167]. Injection of the same megamind targeting MO into this mutant led to the same biological effects as in the wild-type, again strongly suggesting the off-target effect of the MOs as the root cause of the phenotypes originally attributed to the megamind knockdown [167]. The problem with phenotypes caused by non-specific effects is not limited to lncRNAs. For example, RNAi-mediated phenotypes initially associated with knockdown of the protein-coding fruit fly gene pico could not be rescued by an RNAi-resistant pico sequence, again suggesting that the gene was not connected to the observed phenotypes [163].

Furthermore, it is not clear which knockdown method is more specific. Unfortunately, non-specific effects are not limited to siRNAs; shRNAs have also been shown to have them, partially through interfering with the immune response and miRNA levels in the cell [164]. By comparing transcriptome profiles of knockdowns of the same transcripts using siRNAs, ASOs, and CRISPRi, Stojic et al. found very little overlap among the genes whose expression changed in response to the knockdowns, suggesting the existence of method-specific offtarget effects [162]. While the authors suggested that CRISPRi had the fewest numbers of the off-target effects, consistent with the currently prevalent notion that the CRISPR/Cas9 technology in general has high precision and fidelity [168], growing evidence suggests that the off-target effects in this system are also nonnegligible [169-171]. For example, among 12 tested sgRNAs, the off-target binding sites of dCas9 ranged from $\sim 10$ to $>1,000$ in the human genome [169]. Two more recent studies found that Cas9-mediated cytosine base editor has substantial off-target effects in the rice and mouse genomes [170, 171].

Theoretically, targeting multiple sites within the same transcript should increase the reliability of assigning the phenotypes to the transcript. Multiple studies using siRNAs or ASOs rely on this strategy to account for the off-target effects, with as many as 5 independent ASOs per transcript [172]. Presumably, non-specific effects of different siRNAs or other molecules targeting the same transcript would be different, while the common phenotypes should represent the true effect of the targeted transcript. However, while two or three independent MOs targeting respectively the cyrano or megamind IncRNAs produced similar phenotypes [173], these MOs were later shown to cause the phenotypes by effects other than the knockdowns of the target lncRNAs [22, 167]. Still, although phenotype-transcript associations obtained using such strategy do not necessarily represent the underlying biological truths, the strategy represents probably the most essential control for the off-target effects in siRNA/ASO-based experiments and as such must always be followed.

\section{Transcript-independent causes of phenotypes}

Multiple studies are pointing to the fact that an lncRNA locus may not necessarily function only via the transcript itself. For example, using genome-editing 
techniques, Engreitz et al. found that of the $5 \operatorname{lncRNA}$ loci that can influence expression of the neighboring genes, none in fact required the transcripts to mediate this effect [174]. Instead, the phenomenon was mediated by a regulatory cross-talk between neighboring genes also known to occur between protein-coding loci [174]. The IncRNA Airn, located in a well-characterized imprinted locus, is antisense to $I g f 2 r$ and was believed to function by silencing this protein-coding gene $[98,175]$. However, a study employing a series of shortened endogenous Airn lncRNAs showed that the overlap of the IncRNA transcription with the $I g f 2 r$ promoter was responsible for the silencing and excluded a role of the IncRNA in this phenomenon [102]. These findings explain quite well the abovementioned cases of the IncRNAs whose original biological functions were later reclassified as not attributable to the transcripts themselves. Unfortunately, reverse-genetics strategies that do not exclusively target a transcript may incorrectly associate it with a biological process. All in all, while multiple in vivo phenotypes for mouse lncRNA knockouts have been reported, only a handful of those were confirmed by RNA rescue experiments (Table 1), thus leaving a possibility open that the observed defects were not caused by the targeted transcripts per se (Table 1).

\section{Can IncRNAs still have biological functions?}

While it is hard to estimate the fraction of lncRNAs whose reported phenotypes are affected by the issues described above, the consistent emergence of reports pointing to the problems with functional studies of lncRNAs suggest that this fraction might be significant. Moreover, the recent studies point to the fact that a true in vivo phenotype (i.e., truly caused by the transcript per se) of any given lncRNA knockout at least in vertebrates would likely be subtle if at all observable. This brings a natural question of whether these transcripts can be functional at all and, if so, how these functions can be reconciled with the abovementioned phenotypic studies. Below, we will review studies that potentially point to possible modes of biological functionality of lncRNAs that could in turn explain the controversial results described above.

\section{Subtle effects}

A hint to a mode of IncRNA functionality could potentially come from the genome-wide association studies (GWAS). The meta-analysis of these studies shows that most of the phenotype-associated polymorphisms lie in the non-coding parts of the genome [176] and their effects are rather small [177]. While the polymorphisms can function via altering DNA regulatory sequence elements [178], it is quite conceivable that they might function by affecting lncRNAs as well [179]. In fact, the greatest known risk factor for atherosclerosis mapped by GWAS to 9 p21.3 was attributed to the IncRNA ANRIL, believed to function by regulating multiple genes in trans [180, 181]. Single nucleotide polymorphisms in the antisense lncRNA RP11-634B7.4 have been associated with severity of pre-treatment pain in head and neck cancer patients [182]. Furthermore, through extensive analysis of expression profiles of human IncRNAs, the FANTOM consortium found that 1970 lncRNA genes associate with at least one GWAS trait [183].

In such scenario, the small effect sizes typically observed in GWAS studies would be consistent with the subtle phenotypes of lncRNA knockouts. In this model, each lncRNA would contribute a small effect, yet due to their vast numbers, resulting in a significant cumulative biological impact of these transcripts [179].

\section{Cell-type-specific functions}

lncRNAs are well known to have highly cell-typespecific patterns of expression, much more so than protein-coding mRNAs. As shown by the ENCODE consortium, only $10 \%$ of IncRNAs were constitutively expressed as compared to 53\% of mRNAs based on expression analysis across multiple human cell lines [3]. On the other hand, $29 \%$ of the former were detected only in one cell line compared to $7 \%$ of the latter [3]. Highly cell-type- and temporal-specific IncRNA expression patterns have also been shown in vivo [184-187]. Analyses of patterns of expression of various lncRNAs in mammalian brains based either on in situ hybridization [184] or RNA-seq analysis [185] revealed highly restricted patterns confined to neuroanatomical regions, cell types, or subcellular compartments in a genderdependent fashion. And, consistent with this theme, lncRNAs tend to have narrower time windows of expression than mRNAs during early development [186].

The restricted expression feature of lncRNAs fits well with the abovementioned results of the CRISPRi phenotypic screen where $89 \%$ of the positive lncRNAs displayed the phenotypes exclusively in one cell type [137]. Obviously, this feature would significantly complicate detection of a phenotype in vivo since without prior knowledge of the expression patterns of a target lncRNA, the phenotype could be easily missed. Unfortunately, since many lncRNAs were found and characterized in cultured and (predominantly) cancerous cell lines, their in vivo expression profiles are not known.

\section{Functional redundancy}

Functional redundancy of genes is a strategy formed during evolution to counter adverse effects of mutations in genes encoding critical molecular components [188, 189]. And, because of this, knockout of a single gene or its functional element may not show a phenotype [190, 
191]. For example, genes encoding some of the main cell cycle regulators such as $C d k 2, C d k 4$, and others were found to be non-essential for survival in vivo [192, 193]. However, double knockout of $C d k 2$ and $C d k 4$ caused embryonic lethality, demonstrating that $C d k 2$ and $C d k 4$ function redundantly to couple the G1/S phase transition to mitosis [194]. Similarly, the mice lacking either of the sorting nexin family genes $\operatorname{Sn} x 1$ and $\operatorname{Sn} x 2$ are viable and fertile, while the double mutant is embryonic lethal, indicating that these genes have essential yet redundant functions [195]. The PINCH proteins are the key components of the integrin signaling pathway. The mice with cardiac-specific ablation of PINCH1 or germline ablation of PINCH2 displayed no basal cardiac phenotype [196, 197], while the mice with cardiomyocyte-specific double knockout of these genes showed cardiomyopathy, heart failure, and early postnatal lethality [198].

This is also true in the IncRNA world-neither one of the Drosophila roX1 or roX2 genes is essential for survival, while the double mutant is male lethal [39]. Somewhat similar situation has been also observed with Malat1 (Table 1). As mentioned above, the three independently generated Malat1 knockout strains of mice showed no obvious phenotypes [23, 25, 46]. However, crossing these Malat1 knockouts into genetic backgrounds of breast cancer and atherosclerosis mouse models could in fact reveal in vivo effects of the lncRNA on these ailments $[45,47,49]$, although the two breast cancer studies showed contradictory results in terms of the direction of the effect $[45,47]$ (Table 1).

As illustrated by these examples, obtaining an obvious or observable phenotype sometimes requires knockout of several genes. However, this would present a significant complication in an IncRNA functional study not only because of the technical challenges caused by targeted knockouts of multiple lncRNAs in the same genome, but also because the redundant elements for an lncRNA are typically unknown. It is thus reasonable to suggest that at least in some phenotypic studies, the true functions of lncRNAs were masked by other functionally redundant genes.

\section{Missed phenotype}

The phenotype of a given lncRNA can be outside of the scope of the tests performed on the knockout animals. For example, Neat1 lncRNA exclusively localizes to paraspeckles and serves as an architectural component of these nuclear bodies as shown by reverse-genetics studies in cultured cells $[106,199]$. Knockdown of this lncRNA in cultured cells caused disruption of the paraspeckle structure $[106,199]$, while overexpression of Neat1 led to an increase in paraspeckle numbers [106]. On the other hand, Nakagawa et al. reported that Neat1 homozygous knockout mice lacked paraspeckles, yet were viable and fertile, indicating that these nuclear substructures are not essential in vivo and leaving the biological function of Neat1 unresolved [52]. Later, the same group discovered that naturally mated female knockout mice had impaired ability to get pregnant due to defects in formation of corpus luteum, where Neat1 is expressed in adult animals (also see below) [53]. In the same year, another group also found Neat1 in paraspeckles of the mammary gland luminal epithelial cells and essential for mice mammary gland development and lactation [54]. Later on, Neat1 was also found to have in vivo effects under some other specific conditions inducing expression of this lncRNA [5557]. For example, Neat1 can be induced by activation of p53 and ablation of this lncRNA can lead to impaired tumorigenesis in mice [55].

Special consideration has to be given to a possibility that a mutant phenotype may become apparent only in natural conditions as revealed by behavioral analyses of $\mathrm{BC} 1$ knockout mice [200]. The mutant animals lacking this small ( $150 \mathrm{nt})$ non-coding RNA expressed in neurons have no obvious anatomical or neurological defects [201]. However, the mutant mice had decreased exploration behavior under outdoor semi-naturalistic settings, leading to failure to locate distant food sources and higher mortality compared to the wild-type animals [200]. The phenotype was consistent with evolutionary conservation of the $\mathrm{BC} 1$ sequence among rodent species [200], but it would not be revealed under standard laboratory conditions. Noteworthy, the abovementioned study by Akay et al. also failed to detect obvious phenotypes in the $10 \mathrm{C}$. elegans lncRNA knockouts [128]. Only extensive analysis of the mutants alongside the wild-type animals using automated microscopy could reveal the phenotypes affecting individual and population fitness [128].

In summary, even in the protein-coding gene realm, it is common for a knockout animal to have either no observable phenotype or a phenotype revealed only under certain environmental or genetic conditions [202]. Although the authors in the above examples were fortunate in finding the in vivo phenotypes for Neat1 and BC1 (albeit without RNA-based rescue confirmation) and other lncRNAs either in specific cell types or under specific environmental conditions, it is quite possible that some viable and fertile lncRNA knockout animals may harbor yet undiscovered issues associated with the absence of these transcripts.

\section{Emerging solutions to address the challenge of uncovering true biological relevance of IncRNAs Unequivocal assignment of phenotypes to IncRNA transcripts}

Based on the examples described above, it would perhaps not be an exaggeration to state that for many if not most lncRNAs the authenticity of the reported phenotype- 
transcript associations in any system is still ambiguous. It is fairly clear that the main reason for it lies in the issues with the currently used reverse-genetics methods and strategies described above (Fig. 1, also reviewed in Cao et al. [8]). Thus, new technologies and experimental strategies are badly needed. The progress in this area is occurring in at least three directions.

First, development of new RNA-targeting knockdown methods with significantly reduced non-specific and offtarget effects. One such promising approach is represented by the newly developed CRISPR/Cas13 system from Leptotrichia wadei (LwaCas13a) that can be programmed to target a specific transcript via agRNA specifically designed against the latter [203] (Fig. 1). This system could reportedly knockdown nuclear localized lncRNAs such as MALAT1 and XIST [203]. Furthermore, the CRISPR/Cas13 method was reported to have comparable knockdown efficiency as RNAi, but with substantially reduced off-target effects [203]. Finally, 2 mutations in the middle of a 28-nucleotide gRNA (representing only $7 \%$ of the sequence) greatly reduced the efficiency of knockdown, thus allowing for a perfect mutant non-targeting control for each gRNA [203]. This feature potentially gives the CRISPR/Cas13 system an additional strong advantage over methods like RNAi or ASOs where such small sequence changes would not likely abrogate the targeting effects [166] and thus cannot be used to design matching controls.

Our group applied the CRISPR/Cas13 technology to investigate the functionality of vlinc class of nuclear lncRNAs in a large-scale setting [204]. For each vlincRNA, we designed 10 targeting gRNAs and 10 non-targeting mutant control gRNAs differing from the former by $3 \mathrm{mu}-$ tations in the center of the 28-mer gRNA [204]. We have generated a population of human cells constitutively expressing targeting and non-targeting control RNAs in the background of inducible Cas13 [204]. We then assessed changes in the abundance of targeting gRNAs relative to the non-targeting controls for each vlincRNA in response to Cas13 induction and in the context of treatments with various anticancer drugs previously found to upregulate these vlincRNAs at the expression level [204]. Overall, we could find that $64 \%$ (16 out of 25 ) of the tested vlincRNAs were relevant for cellular survival in response to the anticancer drug treatments [204].

Another promising new approach is insertion of selfcleaving ribozymes into lncRNA sequences (Fig. 1). In fact, this strategy has been applied in lncRNA functional studies and resulted in 50-90\% inhibition of the target transcripts, comparable to the other knockdown approaches [205]. This interesting approach has a number of attractive features: (1) depletion should be limited only to the transcript harboring the ribozyme sequence and, as such, should not have any off-target or non- specific effects; (2) it should have minimal effect on the genomic locus (compared to a deletion) and theoretically should not interfere with the process of transcription; (3) it can also work in the nucleus; (4) the ribozyme can be inactivated by point mutations, thus creating a perfect control for any non-specific and off-target effects; and (5) it can be reversed by blocking ASOs or chemical inhibitors to allow for the rescue experiments. However, the method also has some limitations: (1) it involves CRISPR/Cas9-mediated targeted insertion of a ribozyme sequence, making it more complex than other RNAtargeting knockdown methods, and (2) it has the potential to disrupt a functional DNA element overlapping an lncRNA.

Second, the realization that a combination of multiple approaches and/or mutant alleles is needed to fully understand the root cause of a phenotype (Fig. 2). For example, as illustrated in the Hand2as case above, a phenotype truly associated with an lncRNA should be found in deletions of both the gene body and promoter, while the lack of concordance likely indicates transcriptindependent functions $[21,101]$. In another example, the authors used a combination of different methods to separate functions of DNA sequence elements, transcription, and the transcript within the same lncRNA locus [206]. They first performed CRISPR/Cas9-mediated knockout and ASO-mediated knockdown of the BGLT3 lncRNA and found a reduction in transcription of the $\gamma$ globin genes that could be rescued by overexpressing BGLT3 in the knockout cells [206]. The authors also employed CRISPRi to suppress the BGLT3 transcription and found a reduction of the $\gamma$-globin transcription that could not by rescued by overexpressing BGLT3 in these cells [206]. Taken together, the authors provided clear integrative evidence that both the BGLT3 transcription and transcript can upregulate transcription of the $\gamma$-globin genes [206]. A DNA locus and the corresponding transcript can sometimes have distinct or even opposing roles. In embryonic stem cells, CRISPR/Cas9mediated genomic deletion of the lncRNA Haunt downregulated the HOXA gene cluster, while depletion of the Haunt transcript by RNAi, polyA insertion, or promoter deletion upregulated the HOXA genes [207]. However, restoring expression of the Haunt transcript via knockin into the original genomic location in the background of the homozygous Haunt deletion mutant could not rescue the downregulation of the HOXA expression [207]. The authors concluded that the Haunt genomic locus contains DNA elements with potential enhancer functions for the HOXA genes while the IncRNA can potentially silence them [207].

In summary, a single reverse-genetics method is unlikely to yield a conclusive answer as to lncRNA biological function especially if it does not explicitly target 
RNA, calling for a combination of multiple approaches and careful analysis to separate different possible causes of the observed effects. However, caution should also be exercised when interpreting inconsistent results from different experimental approaches because each reversegenetics method might target unique pools of transcripts derived from the same locus. For example, while both ASO- and RNAi-mediated knockdowns resulted in similar levels of depletion of the lncRNA linc-HOXA1, only the former method affected a specific subset of lincHOXA1 RNA molecules-those associated with sites of transcription-and led to the cis phenotype of suppression of the nearby Hoxa1 gene expression [208].

Still, presence of several DNA elements with different functions overlapping an lncRNA transcript-not an unlikely scenario-could theoretically mislead interpretation of even carefully constructed genome-editing experiments (Fig. 1). As such, there is a growing realization that RNA-based rescue experiments are required in lncRNA functional studies based on genomeediting tools (Fig. 2). For example, in addition to the studies in nematode and fruit fly described above [126, 127], a handful of mammalian knockout phenotypes have been validated by RNA rescue (Table 1). For example, restoring the Fendrr lncRNA expression in the corresponding knockout rescued the majority of the abnormal phenotypes in the heart and body wall development [58]. Likewise, ectopic expression of the Firre lncRNA in the Firre knockout mouse rescued the defects in hematopoiesis and alterations in gene expression [59]. More interestingly, through RNA-based rescue, phenotypes of the $H 19$ knockout mice previously attributed to the cis effect of the H19 locus on the local chromatin environment $[32,33]$ were proven to be also caused by the H19 transcript itself [34] (Table 1). However, such experiments could be quite challenging for lncRNAs. First, the size of many lncRNAs, particularly the vlincRNA species with the lengths over $50 \mathrm{~kb}$ [209], makes their overexpression technically difficult. Second, the nature of the functional transcript may not always be known. For example, some lncRNAs like Xist and Neat1 have multiple isoforms, which may possess different functions [52, 210]. Third, ectopic expression would not work in cases where the genomic locations are important, for example in the cases of cis-regulatory lncRNAs which could be numerous in the human genome [9]. In fact, as mentioned above, such validation is rare even for the "gold standard" IncRNAs. Finally, it is noteworthy that even positive RNA-based rescue outcomes may sometimes have flaws. For example, the megamind and cyrano lncRNAs were proven to be functional via RNAbased rescue [173]; however, later studies found that the observed phenotypes were due to non-specific effects of the reverse-genetics method employed [22, 167]. Still, in the contexts of the techniques that cannot exclusively target transcripts, RNA-based rescue experiments would likely remain critical in providing unambiguous connections between lncRNAs and phenotypes.

\section{Choice of a biological system for reverse-genetics studies}

A phenotype un-ambiguously attributable to an lncRNA in an animal model would always hold the key to answering the question of whether the lncRNA has biological function. However, obtaining such a phenotype is extremely challenging, not in a small part due to a highly restricted expression pattern of a typical lncRNA that makes obvious, global defects caused by its knockout less likely. Indeed, the phenotype(s) would likely associate with the cells or tissues expressing the lncRNA (Fig. 2), as exemplified by Neat1 where the phenotypes were found in specific cell types and conditions expressing this transcript (see above). In another example, expression of the Firre IncRNA is the highest in the hematopoietic stem cells and, as expected, knockout of that lncRNA in mice caused defects in the hematopoiesis [59]. Still, a knockout of an lncRNA expressed in a limited number of cells in an adult animal or even fetus is less likely to cause an obvious defect. As such, embarking on an in vivo phenotypic experiment would only be warranted if the expression profile of a target lncRNA is reasonably well understood. In this respect, while the community has access to a number of comprehensive expression datasets in humans (ENCODE [211], GTEX [212], TCGA [213]), mouse (Mouse ENCODE [214]) or both (FANTOM5 [183, 215]), an atlas of the spatio-temporal expression patterns of lncRNAs in animal models would be highly desirable for any future reverse-genetics studies.

On the other hand, functional studies on cultured cells are unavoidable in a number of scenarios and also offer a number of advantages compared to the whole-animal studies (Fig. 2). First, as mentioned above, many lncRNAs have been found only in cell lines and their patterns of expression in vivo are not known. Second, due to low sequence conservation of mammalian IncRNAs [138], the homologs of human transcripts in animal models may be unknown due to deep divergence in sequence and structure [216] or may not even exist. Third, human lncRNAs found only in cell lines can still have properties making them attractive for in-depth analysis, for example involvement in drug resistance, leaving the cell lines as the only logical choice for these assays. Fourth, cell lines are significantly cheaper and easier to manipulate than animals. Finally, cultured cells allow for the high-throughput population-level assays ideally suited for detecting subtle phenotypes based on measuring small changes in cell populations by deep sequencing of barcodes inserted into the cells. As described above, 
such strategies based on libraries of shRNAs or sgRNAs in RNAi-, CRISPR/Cas9-, CRISPR/dCas9-, or CRISPR/ Cas13-based assays could annotate biological functions of the target genes based on detection of subtle changes in viability or stress resistance as shown in multiple studies [133-137, 204]. Importantly, large-scale screens allow relative quantitation of the effect of each lncRNA on cellular fitness by measuring fold change-depletion or enrichment-for each shRNAs or sgRNAs. This would allow for ranking of all lncRNAs according to their biological effects in multiple cell types-something that would be hard to achieve in in vivo studies. Arguably, such studies using proper controls and multiple targets against each transcript could indeed be quite revealing in annotating biological functions of lncRNAs (Fig. 2).

Finally, it should also be realized that an IncRNA may in fact encode short peptide(s) and thus represent an mRNA. Moreover, such peptides can have biological functions as revealed by the phenotypes of the corresponding knockouts. For example, a spliced human transcript originally annotated as the lncRNA LINC00948 was later realized to represent an mRNA encoding a 46-amino acid micropeptide myoregulin [217]. In vivo knockout of the peptide resulted in a muscle performance phenotype [217]. The number of such lncRNAs turned mRNAs encoding functional peptides is steadily growing $[103,218,219]$. Since the presence of a peptide-encoding open reading frame might be difficult to discern from sequence analysis alone, it is quite probable that an lncRNA initially associated with a specific biological process might actually function as an mRNA.

\section{Conclusions}

Perhaps the major challenge in the lncRNA field is to prove beyond a reasonable doubt the biological significance of these transcripts not only in cultured cells but also at the organismal level. As of now, in vivo phenotypes in reverse-genetics studies appear rather subtle and/or highly redundant for most of these transcripts. However, the challenges posed by these negative outcomes may also represent opportunities as we might be getting hints as to the actual modes of functioning of lncRNAs in vivo. However, novel experimental methods and strategies have to be adopted to match these challenges and to resolve the debate about the functionality of this fascinating class of RNAs.

\section{Supplementary information}

Supplementary information accompanies this paper at https://doi.org/10. 1186/s13059-020-01994-5.

Additional file 1. Review history.

\section{Acknowledgements}

PK wishes to acknowledge support from the National Science Foundation of China (grant no. 31671382). DX wishes to acknowledge support from the Scientific Research Funds of Huaqiao University. FG and YC wish to acknowledge support from the Postgraduates Innovative Fund in Scientific Research from Huaqiao University.

\section{Peer review information}

Andrew Cosgrove was the primary editor of this article and managed its editorial process and peer review in collaboration with the rest of the editorial team.

\section{Review history}

The review history is available as Additional file 1.

\section{Authors' contributions}

PK and DX conceived and wrote the manuscript. FG, YC, and DX generated the table. YC generated the figures. FG and YC contributed to the writing of the manuscript. The authors viewed and approved the final manuscript.

\section{Funding}

This work was supported by a grant from the National Science Foundation of China (No. 31671382) to PK. DX was supported by the Scientific Research Funds of Huaqiao University. FG and YC are supported by the Postgraduates Innovative Fund in Scientific Research from Huaqiao University.

\section{Competing interests}

The authors declare that they have no competing interests.

Published online: 14 April 2020

\section{References}

1. Kapranov P, Cawley SE, Drenkow J, Bekiranov S, Strausberg RL, Fodor SP, Gingeras TR. Large-scale transcriptional activity in chromosomes 21 and 22. Science. 2002;296:916-9.

2. Consortium F. RIKEN Genome Exploration Research Group and Genome Science Group (Genome Network Project Core Group) The transcriptional landscape of the mammalian genome. Science. 2005;309:1559-63.

3. Djebali S, Davis CA, Merkel A, Dobin A, Lassmann T, Mortazavi A, Tanzer A, Lagarde J, Lin W, Schlesinger F, et al. Landscape of transcription in human cells. Nature. 2012;489:101-8.

4. Kapranov P, Cheng J, Dike S, Nix DA, Duttagupta R, Willingham AT, Stadler PF, Hertel J, Hackermuller J, Hofacker IL, et al. RNA maps reveal new RNA classes and a possible function for pervasive transcription. Science. 2007; 316:1484-8.

5. Laurent GS, Wahlestedt C, Kapranov P. The landscape of long noncoding RNA classification. Trends Genet. 2015;31:239-51.

6. Schlackow M, Nojima T, Gomes T, Dhir A, Carmo-Fonseca M, Proudfoot NJ. Distinctive patterns of transcription and RNA processing for human lincRNAs. Mol Cell. 2017;65:25-38.

7. Derrien $T$, Johnson R, Bussotti G, Tanzer A, Djebali S, Tilgner H, Guernec $G$, Martin D, Merkel A, Knowles DG, et al. The GENCODE v7 catalog of human long noncoding RNAs: analysis of their gene structure, evolution, and expression. Genome Res. 2012;22:1775-89.

8. Cao H, Wahlestedt C, Kapranov P. Strategies to annotate and characterize long noncoding RNAs: advantages and piffalls. Trends Genet. 2018;34:704-21.

9. Kopp F, Mendell JT. Functional classification and experimental dissection of long noncoding RNAs. Cell. 2018;172:393-407.

10. Vance $\mathrm{KW}$, Ponting CP. Transcriptional regulatory functions of nuclear long noncoding RNAs. Trends Genet. 2014;30:348-55.

11. Rinn JL, Chang HY. Genome regulation by long noncoding RNAs. Annu Rev Biochem. 2012;81:145-66.

12. Blokhin I, Khorkova O, Hsiao J, Wahlestedt C. Developments in IncRNA drug discovery: where are we heading? Expert Opin Drug Discov. 2018;13:837-49.

13. Kung JT, Colognori D, Lee JT. Long noncoding RNAs: past, present, and future. Genetics. 2013;193:651-69.

14. Mercer TR, Mattick JS. Structure and function of long noncoding RNAs in epigenetic regulation. Nat Struct Mol Biol. 2013;20:300-7.

15. Bergmann JH, Spector DL. Long non-coding RNAs: modulators of nuclear structure and function. Curr Opin Cell Biol. 2014;26:10-8. 
16. Struhl K. Transcriptional noise and the fidelity of initiation by RNA polymerase II. Nat Struct Mol Biol. 2007;14:103-5.

17. Eddy SR. The C-value paradox, junk DNA and ENCODE. Curr Biol. 2012;22: R898-9.

18. Doolittle WF. Is junk DNA bunk? A critique of ENCODE. Proc Natl Acad Sci U S A. 2013;110:5294-300.

19. Palazzo AF, Gregory TR. The case for junk DNA. PLoS Genet. 2014;10: e1004351.

20. Raabe CA, Brosius J. Does every transcript originate from a gene? Ann N Y Acad Sci. 2015;1341:136-48.

21. Han X, Luo S, Peng G, Lu JY, Cui G, Liu L, Yan P, Yin Y, Liu W, Wang R, et al. Mouse knockout models reveal largely dispensable but context-dependent functions of IncRNAs during development. J Mol Cell Biol. 2018;10:175-8.

22. Goudarzi M, Berg K, Pieper LM, Schier AF. Individual long non-coding RNAs have no overt functions in zebrafish embryogenesis, viability and fertility. Elife. 2019;8:e40815.

23. Eissmann M, Gutschner T, Hammerle M, Gunther S, Caudron-Herger M Gross M, Schirmacher P, Rippe K, Braun T, Zornig M, Diederichs S. Loss of the abundant nuclear non-coding RNA MALAT1 is compatible with life and development. RNA Biol. 2012;9:1076-87.

24. Kolling M, Genschel C, Kaucsar T, Hubner A, Rong S, Schmitt R, SorensenZender I, Haddad G, Kistler A, Seeger H, et al. Hypoxia-induced long noncoding RNA Malat1 is dispensable for renal ischemia/reperfusion-injury. Sci Rep. 2018;8:3438

25. Nakagawa S, Ip JY, Shioi G, Tripathi V, Zong X, Hirose T, Prasanth KV. Malat1 is not an essential component of nuclear speckles in mice. Rna. 2012;18:1487-99.

26. Amandio AR, Necsulea A, Joye E, Mascrez B, Duboule D. Hotair is dispensible for mouse development. PLoS Genet. 2016;12:e1006232.

27. Kleaveland B, Shi CY, Stefano J, Bartel DP. A network of noncoding regulatory RNAs acts in the mammalian brain. Cell. 2018;174:350-62 e317.

28. Dimitrova N, Zamudio JR, Jong RM, Soukup D, Resnick R, Sarma K, Ward AJ, Raj A, Lee JT, Sharp PA, Jacks T. LincRNA-p21 activates p21 in cis to promote Polycomb target gene expression and to enforce the G1/S checkpoint. Mol Cell. 2014:54:777-90.

29. Stafford DA, Dichmann DS, Chang JK, Harland RM. Deletion of the sclerotome-enriched IncRNA PEAT augments ribosomal protein expression. Proc Natl Acad Sci U S A. 2017;114:101-6.

30. Lee $Y$, Park C, Lee S, Lee D, Kim J. Isolation and functional examination of the long non-coding RNA Redrum. Mol Cells. 2018;41:134-9.

31. Oliver PL, Chodroff RA, Gosal A, Edwards B, Cheung AF, Gomez-Rodriguez J, Elliot G, Garrett LJ, Lickiss T, Szele F, et al. Disruption of Visc-2, a brainexpressed conserved long noncoding RNA, does not elicit an overt anatomical or behavioral phenotype. Cereb Cortex. 2015;25:3572-85.

32. Leighton PA, Ingram RS, Eggenschwiler J, Efstratiadis A, Tilghman SM. Disruption of imprinting caused by deletion of the $\mathrm{H} 19$ gene region in mice. Nature. 1995;375:34-9.

33. Ripoche MA, Kress C, Poirier F, Dandolo L. Deletion of the H19 transcription unit reveals the existence of a putative imprinting control element. Genes Dev. 1997:11:1596-604.

34. Gabory A, Ripoche MA, Le Digarcher A, Watrin F, Ziyyat A, Forne T, Jammes $\mathrm{H}$, Ainscough JF, Surani MA, Journot L, Dandolo L. H19 acts as a trans regulator of the imprinted gene network controlling growth in mice. Development. 2009:136:3413-21.

35. Yoshimizu T, Miroglio A, Ripoche MA, Gabory A, Vernucci M, Riccio A, Colnot S, Godard C, Terris B, Jammes H, Dandolo L. The H19 locus acts in vivo as a tumor suppressor. Proc Natl Acad Sci U S A. 2008;105:12417-22.

36. Martinet C, Monnier P, Louault Y, Benard M, Gabory A, Dandolo L. H19 controls reactivation of the imprinted gene network during muscle regeneration. Development. 2016;143:962-71.

37. Schultheiss CS, Laggai S, Czepukojc B, Hussein UK, List M, Barghash A, Tierling S, Hosseini K, Golob-Schwarzl N, Pokorny J, et al. The long noncoding RNA H19 suppresses carcinogenesis and chemoresistance in hepatocellular carcinoma. Cell Stress. 2017;1:37-54

38. Pope C, Piekos SC, Chen L, Mishra S, Zhong XB. The role of H19, a long noncoding RNA, in mouse liver postnatal maturation. PLoS One. 2017;12:e0187557.

39. Meller VH, Rattner BP. The roX genes encode redundant male-specific lethal transcripts required for targeting of the MSL complex. EMBO J. 2002;21: 1084-91.

40. Marahrens Y, Panning B, Dausman J, Strauss W, Jaenisch R. Xist-deficient mice are defective in dosage compensation but not spermatogenesis. Genes Dev. 1997;11:156-66.
41. Senner CE, Nesterova TB, Norton S, Dewchand H, Godwin J, Mak W, Brockdorff N. Disruption of a conserved region of Xist exon 1 impairs Xist RNA localisation and $X$-linked gene silencing during random and imprinted X chromosome inactivation. Development. 2011:138:1541-50.

42. Yildirim E, Kirby JE, Brown DE, Mercier F, Sadreyev RI, Scadden DT, Lee JT. Xist RNA is a potent suppressor of hematologic cancer in mice. Cell. 2013. 152:727-42.

43. Yang L, Kirby JE, Sunwoo H, Lee JT. Female mice lacking Xist RNA show partial dosage compensation and survive to term. Genes Dev. 2016;30:1747-60.

44. Xing F, Liu Y, Wu SY, Wu K, Sharma S, Mo YY, Feng J, Sanders S, Jin G, Singh $\mathrm{R}$, et al. Loss of XIST in breast cancer activates MSN-c-Met and reprograms microglia via exosomal miRNA to promote brain metastasis. Cancer Res. 2018;78:4316-30

45. Kim J, Piao HL, Kim BJ, Yao F, Han Z, Wang Y, Xiao Z, Siverly AN, Lawhon SE, Ton BN, et al. Long noncoding RNA MALAT1 suppresses breast cancer metastasis. Nat Genet. 2018:50:1705-15

46. Zhang B, Arun G, Mao YS, Lazar Z, Hung G, Bhattacharjee G, Xiao X, Booth CJ, Wu J, Zhang C, Spector DL. The IncRNA Malat1 is dispensable for mouse development but its transcription plays a cis-regulatory role in the adult. Cell Rep. 2012;2:111-23.

47. Arun G, Diermeier S, Akerman M, Chang KC, Wilkinson JE, Hearn S, Kim Y, MacLeod $A R$, Krainer AR, Norton $L$, et al. Differentiation of mammary tumors and reduction in metastasis upon Malat1 IncRNA loss. Genes Dev. 2016;30:34-51.

48. Zhang X, Tang X, Liu K, Hamblin MH, Yin K-J. Long noncoding RNA Malat1 regulates cerebrovascular pathologies in ischemic stroke. J Neurosci. 2017; 37:1797-806.

49. Cremer S, Michalik KM, Fischer A, Pfisterer L, Jae N, Winter C, Boon RA, Muhly-Reinholz M, John D, Uchida S, et al. Hematopoietic deficiency of the long noncoding RNA MALAT1 promotes atherosclerosis and plaque inflammation. Circulation. 2019:139:1320-34.

50. Li L, Liu B, Wapinski OL, Tsai MC, Qu K, Zhang J, Carlson JC, Lin M, Fang F, Gupta RA, et al. Targeted disruption of Hotair leads to homeotic transformation and gene derepression. Cell Rep. 2013;5:3-12.

51. Lai KM, Gong G, Atanasio A, Rojas J, Quispe J, Posca J, White D, Huang M, Fedorova D, Grant C, et al. Diverse phenotypes and specific transcription patterns in twenty mouse lines with ablated lincRNAs. PLoS One. 2015;10: e0125522.

52. Nakagawa S, Naganuma T, Shioi G, Hirose T. Paraspeckles are subpopulation-specific nuclear bodies that are not essential in mice. J Cell Biol. 2011;193:31-9.

53. Nakagawa S, Shimada M, Yanaka K, Mito M, Arai T, Takahashi E, Fujita Y, Fujimori T, Standaert L, Marine JC, Hirose T. The IncRNA Neat1 is required for corpus luteum formation and the establishment of pregnancy in a subpopulation of mice. Development. 2014;141:4618-27.

54. Standaert L, Adriaens C, Radaelli E, Van Keymeulen A, Blanpain C, Hirose T, Nakagawa S, Marine JC. The long noncoding RNA Neat1 is required for mammary gland development and lactation. RNA. 2014:20:1844-9.

55. Adriaens C, Standaert L, Barra J, Latil M, Verfaillie A, Kalev P, Boeckx B, Wijnhoven PW, Radaelli E, Vermi W, et al. p53 induces formation of NEAT1 IncRNA-containing paraspeckles that modulate replication stress response and chemosensitivity. Nat Med. 2016;22:861-8.

56. Ahmed ASI, Dong K, Liu J, Wen T, Yu L, Xu F, Kang X, Osman I, Hu G, Bunting KM, et al. Long noncoding RNA NEAT1 (nuclear paraspeckle assembly transcript 1) is critical for phenotypic switching of vascular smooth muscle cells. Proc Natl Acad Sci U S A. 2018:115:E8660-7.

57. Zhang P, Cao L, Zhou R, Yang X, Wu M. The IncRNA Neat1 promotes activation of inflammasomes in macrophages. Nat Commun. 2019;10:1495.

58. Grote P, Wittler L, Hendrix D, Koch F, Wahrisch S, Beisaw A, Macura K, Blass $G$, Kellis M, Werber M, Herrmann BG. The tissue-specific IncRNA Fendrr is an essential regulator of heart and body wall development in the mouse. Dev Cell. 2013;24:206-14.

59. Lewandowski JP, Lee JC, Hwang T, Sunwoo H, Goldstein JM, Groff AF, Chang NP, Mallard W, Williams A, Henao-Meija J, et al. The Firre locus produces a trans-acting RNA molecule that functions in hematopoiesis. Nat Commun. 2019;10:5137.

60. Ye B, Liu B, Yang L, Zhu X, Zhang D, Wu W, Zhu P, Wang Y, Wang S, Xia P, et al. LncKdm2b controls self-renewal of embryonic stem cells via activating expression of transcription factor Zbtb3. EMBO J. 2018:37:e97174.

61. Sun F, Zhuang Y, Zhu H, Wu H, Li D, Zhan L, Yang W, Yuan Y, Xie Y, Yang S, et al. LncRNA PCFL promotes cardiac fibrosis via miR-378/GRB2 pathway following myocardial infarction. J Mol Cell Cardiol. 2019;133:188-98. 
62. Wang Z, Zhang XJ, Ji YX, Zhang P, Deng KQ, Gong J, Ren S, Wang X, Chen I, Wang $\mathrm{H}$, et al. The long noncoding RNA Chaer defines an epigenetic checkpoint in cardiac hypertrophy. Nat Med. 2016;22:1131-9.

63. Guo $X, X u$ Y, Wang Z, Wu Y, Chen J, Wang G, Lu C, Jia W, Xi J, Zhu S, et al. A Linc1405/Eomes complex promotes cardiac mesoderm specification and cardiogenesis. Cell Stem Cell. 2018;22:893-908 e896.

64. Atianand MK, Hu W, Satpathy AT, Shen Y, Ricci EP, Alvarez-Dominguez JR, Bhatta A, Schattgen SA, McGowan JD, Blin J, et al. A long noncoding RNA lincRNA-EPS acts as a transcriptional brake to restrain inflammation. Cell. 2016;165:1672-85.

65. Liu B, Ye B, Yang L, Zhu X, Huang G, Zhu P, Du Y, Wu J, Qin X, Chen R, et al. Long noncoding RNA IncKdm2b is required for ILC3 maintenance by initiation of Zfp292 expression. Nat Immunol. 2017;18:499-508.

66. Thomas AA, Feng B, Chakrabarti S. ANRIL regulates production of extracellular matrix proteins and vasoactive factors in diabetic complications. Am J Physiol Endocrinol Metab. 2018;314:E191-200.

67. Zhao XY, Li S, DelProposto JL, Liu T, Mi L, Porsche C, Peng X, Lumeng CN, Lin JD. The long noncoding RNA Blnc1 orchestrates homeostatic adipose tissue remodeling to preserve metabolic health. Mol Metab. 2018;14:60-70.

68. Zhao XY, Xiong X, Liu T, Mi L, Peng X, Rui C, Guo L, Li S, Li X, Lin JD. Long noncoding RNA licensing of obesity-linked hepatic lipogenesis and NAFLD pathogenesis. Nat Commun. 2018;9:2986.

69. Li CJ, Xiao Y, Yang M, Su T, Sun X, Guo Q, Huang Y, Luo XH. Long noncoding RNA Bmncr regulates mesenchymal stem cell fate during skeletal aging. J Clin Invest. 2018;128:5251-66.

70. Arnes L, Akerman I, Balderes D, Ferrer J, Sussel L. Blinc1 encodes a long noncoding RNA that regulates islet $\beta$-cell formation and function. Genes Dev. 2016;30:502-7.

71. Ballarino M, Cipriano A, Tita R, Santini T, Desideri F, Morlando M, Colantoni A, Carrieri C, Nicoletti C, Musaro A, et al. Deficiency in the nuclear long noncoding RNA Charme causes myogenic defects and heart remodeling in mice. EMBO J. 2018;37:e99697.

72. Ponnusamy M, Liu F, Zhang YH, Li RB, Zhai M, Liu F, Zhou LY, Liu CY, Yan $\mathrm{KW}$, Dong YH, et al. Long noncoding RNA CPR (cardiomyocyte proliferation regulator) regulates cardiomyocyte proliferation and cardiac repair. Circulation. 2019;139:2668-84.

73. Schmitt AM, Garcia JT, Hung T, Flynn RA, Shen Y, Qu K, Payumo AY, Peresda-Silva A, Broz DK, Baum R, et al. An inducible long noncoding RNA amplifies DNA damage signaling. Nat Genet. 2016:48:1370-6.

74. Bond AM, Vangompel MJW, Sametsky EA, Clark MF, Savage JC, Disterhoft JF, Kohtz JD. Balanced gene regulation by an embryonic brain ncRNA is critical for adult hippocampal GABA circuitry. Nat Neurosci. 2009;12:1020-7.

75. Sauvageau M, Goff LA, Lodato S, Bonev B, Groff AF, Gerhardinger C, Sanchez-Gomez DB, Hacisuleyman E, Li E, Spence M, et al. Multiple knockout mouse models reveal lincRNAs are required for life and brain development. Elife. 2013;2:e01749

76. Brajic A, Franckaert D, Burton O, Bornschein S, Calvanese AL, Demeyer S, Cools J, Dooley J, Schlenner S, Liston A. The long non-coding RNA Flatr anticipates Foxp3 expression in regulatory T cells. Front Immunol. 2018;9:1989.

77. Zemmour D, Pratama A, Loughhead SM, Mathis D, Benoist C. Flicr, a long noncoding RNA, modulates Foxp3 expression and autoimmunity. Proc Natl Acad Sci U S A. 2017;114:E3472-80.

78. Szafranski P, Karolak JA, Lanza D, Gajecka M, Heaney J, Stankiewicz P. CRISPR/Cas9-mediated deletion of IncRNA Gm26878 in the distant Foxf1 enhancer region. Mamm Genome. 2017;28:275-82

79. Ip JY, Sone M, Nashiki C, Pan Q, Kitaichi K, Yanaka K, Abe T, Takao K, Miyakawa T, Blencowe BJ, Nakagawa S. Gomafu IncRNA knockout mice exhibit mild hyperactivity with enhanced responsiveness to the psychostimulant methamphetamine. Sci Rep. 2016;6:27204.

80. Takahashi N, Okamoto A, Kobayashi R, Shirai M, Obata Y, Ogawa H, Sotomaru Y, Kono T. Deletion of Gtl2, imprinted non-coding RNA, with its differentially methylated region induces lethal parent-origin-dependent defects in mice. Hum Mol Genet. 2009;18:1879-88.

81. Zhou Y, Cheunsuchon P, Nakayama Y, Lawlor MW, Zhong Y, Rice KA, Zhang L, Zhang X, Gordon FE, Lidov HG, et al. Activation of paternally expressed genes and perinatal death caused by deletion of the Gtl2 gene. Development. 2010;137:2643-52.

82. Zhou $Y$, Zhang $X$, Klibanski A. MEG3 noncoding RNA: a tumor suppressor. J Mol Endocrinol. 2012;48:R45-53.
83. Gordon FE, Nutt CL, Cheunsuchon P, Nakayama Y, Provencher KA, Rice KA, Zhou Y, Zhang X, Klibanski A. Increased expression of angiogenic genes in the brains of mouse meg3-null embryos. Endocrinology. 2010;151:2443-52.

84. Yu X, Zhang Y, Li T, Ma Z, Jia H, Chen Q, Zhao Y, Zhai L, Zhong R, Li C, et al. Long non-coding RNA Linc-RAM enhances myogenic differentiation by interacting with MyoD. Nat Commun. 2017:8:14016.

85. Cai B, Zhang Y, Zhao Y, Wang J, Li T, Zhang Y, Jiang Y, Jin X, Xue G, Li P, et al. Long noncoding RNA-DACH1 (dachshund homolog 1) regulates cardiac function by inhibiting SERCA2a (sarcoplasmic reticulum calcium ATPase 2a). Hypertension. 2019;74:833-42.

86. Zhu P, Wu J, Wang Y, Zhu X, Lu T, Liu B, He L, Ye B, Wang S, Meng S, et al. LncGata6 maintains stemness of intestinal stem cells and promotes intestinal tumorigenesis. Nat Cell Biol. 2018:20:1134-44.

87. Zhu M, Liu J, Xiao J, Yang L, Cai M, Shen H, Chen X, Ma Y, Hu S, Wang Z, et al. Lnc-mg is a long non-coding RNA that promotes myogenesis. Nat Commun. 2017:8:14718.

88. Dallner OS, Marinis JM, Lu YH, Birsoy K, Werner E, Fayzikhodjaeva G, Dill BD, Molina H, Moscati A, Kutalik Z, et al. Dysregulation of a long noncoding RNA reduces leptin leading to a leptin-responsive form of obesity. Nat Med. 2019;25:507-16

89. Maarouf M, Chen B, Chen Y, Wang XM, Rai KR, Zhao Z, Liu S, Li Y, Xiao M, Chen J. Identification of IncRNA-155 encoded by MIR155HG as a novel regulator of innate immunity against influenza A virus infection. Cell Microbiol. 2019;21:e13036.

90. Zhang L, Xue Z, Yan J, Wang J, Liu Q, Jiang H. LncRNA Riken-201 and Riken203 modulates neural development by regulating the Sox6 through sequestering miRNAs. Cell Prolif. 2019;52:e12573.

91. Perry RB, Hezroni H, Goldrich MJ, Ulitsky I. Regulation of neuroregeneration by long noncoding RNAs. Mol Cell. 2018;72:553-67 e555.

92. Liu S, Sheng L, Miao H, Saunders TL, MacDougald OA, Koenig RJ, Xu B. SRA gene knockout protects against diet-induced obesity and improves glucose tolerance. J Biol Chem. 2014:289:13000-9.

93. Jin JJ, Lv W, Xia P, Xu ZY, Zheng AD, Wang XJ, Wang SS, Zeng R, Luo HM, Li GL, Zuo B. Long noncoding RNA SYISL regulates myogenesis by interacting with polycomb repressive complex 2. Proc Natl Acad Sci U S A. 2018;115: E9802-11.

94. Lee JT. Disruption of imprinted $X$ inactivation by parent-of-origin effects at Tsix. Cell. 2000;103:17-27.

95. Sado T, Wang Z, Sasaki H, Li E. Regulation of imprinted X-chromosome inactivation in mice by Tsix. Development. 2001;128:1275-86.

96. Wichman L, Somasundaram S, Breindel C, Valerio DM, Mccarrey JR, Hodges CA, Khalil AM. Dynamic expression of long noncoding RNAs reveals their potential roles in spermatogenesis and fertility. Biol Reprod. 2017:97:313-23.

97. Anguera MC, Ma W, Clift D, Namekawa SH, Kelleher RJ, Lee JT. Tsx produces a long noncoding RNA and has general functions in the germline, stem cells, and brain. PLoS Genet. 2011;7:e1002248.

98. Sleutels F, Zwart R, Barlow DP. The non-coding Air RNA is required for silencing autosomal imprinted genes. Nature. 2002:415:810-3.

99. Mulati M, Kobayashi Y, Takahashi A, Numata H, Saito M, Hiraoka Y, Ochi H, Sato $S$, Ezura $Y$, Yuasa $M$, et al. The long noncoding RNA Crnde regulates osteoblast proliferation through the Wnt/beta-catenin signaling pathway in mice. Bone. 2020;130:115076.

100. Wang Y, Zhu P, Wang J, Zhu X, Luo J, Meng S, Wu J, Ye B, He L, Du Y, et al. Long noncoding RNA IncHand2 promotes liver repopulation via c-Met signaling. J Hepatol. 2018;69:861-72.

101. Anderson KM, Anderson DM, McAnally JR, Shelton JM, Bassel-Duby R, Olson EN. Transcription of the non-coding RNA upperhand controls Hand2 expression and heart development. Nature. 2016;539:433-6.

102. Latos PA, Pauler FM, Koerner MV, Senergin HB, Hudson QJ, Stocsits RR, Allhoff W, Stricker SH, Klement RM, Warczok KE, et al. Airn transcriptional overlap, but not its IncRNA products, induces imprinted Igf2r silencing. Science. 2012;338:1469-72.

103. Szafron LM, Balcerak A, Grzybowska EA, Pienkowska-Grela B, Felisiak-Golabek A, Podgorska A, Kulesza M, Nowak N, Pomorski P, Wysocki J, et al. The novel gene CRNDE encodes a nuclear peptide (CRNDEP) which is overexpressed in highly proliferating tissues. PLoS One. 2015;10:e0127475.

104. Mattick JS, Rinn JL. Discovery and annotation of long noncoding RNAs. Nat Struct Mol Biol. 2015;22:5-7.

105. Marchese FP, Raimondi I, Huarte M. The multidimensional mechanisms of long noncoding RNA function. Genome Biol. 2017;18:206. 
106. Clemson CM, Hutchinson JN, Sara SA, Ensminger AW, Fox AH, Chess A, Lawrence JB. An architectural role for a nuclear noncoding RNA: NEAT1 RNA is essential for the structure of paraspeckles. Mol Cell. 2009;33:717-26.

107. Lazorthes S, Vallot C, Briois S, Aguirrebengoa M, Thuret JY, St Laurent G, Rougeulle C, Kapranov P, Mann C, Trouche D, Nicolas E. A vlincRNA participates in senescence maintenance by relieving H2AZ-mediated repression at the INK4 locus. Nat Commun. 2015;6:5971.

108. Khaitan D, Dinger ME, Mazar J, Crawford J, Smith MA, Mattick JS, Perera RJ. The melanoma-upregulated long noncoding RNA SPRY4-IT1 modulates apoptosis and invasion. Cancer Res. 2011;71:3852-62.

109. Zhang Y, Pitchiaya S, Cieslik M, Niknafs YS, Tien JC, Hosono Y, Iyer MK, Yazdani S, Subramaniam S, Shukla SK, et al. Analysis of the androgen receptor-regulated IncRNA landscape identifies a role for ARLNC1 in prostate cancer progression. Nat Genet. 2018;50:814-24.

110. Meng Q, Wang K, Brunetti T, Xia Y, Jiao C, Dai R, Fitzgerald D, Thomas A, Jay $L$, Eckart $H$, et al. The DGCR5 long noncoding RNA may regulate expression of several schizophrenia-related genes. Sci Transl Med. 2018;10:eaat6912.

111. Ning S, Zhang J, Wang P, Zhi H, Wang J, Liu Y, Gao Y, Guo M, Yue M, Wang L, Li X. Lnc2Cancer: a manually curated database of experimentally supported IncRNAs associated with various human cancers. Nucleic Acids Res. 2016:44:D980-5.

112. Bao Z, Yang Z, Huang Z, Zhou Y, Cui Q, Dong D. LncRNADisease 2.0: an updated database of long non-coding RNA-associated diseases. Nucleic Acids Res. 2019;47:D1034-7.

113. Volders PJ, Anckaert J, Verheggen K, Nuytens J, Martens L, Mestdagh P, Vandesompele J. LNCipedia 5: towards a reference set of human long noncoding RNAs. Nucleic Acids Res. 2019;47:D135-9.

114. Wahlestedt C. Targeting long non-coding RNA to therapeutically upregulate gene expression. Nat Rev Drug Discov. 2013;12:433-46.

115. Ho TT, Zhou N, Huang J, Koirala P, Xu M, Fung R, Wu F, Mo YY. Targeting non-coding RNAs with the CRISPR/Cas9 system in human cell lines. Nucleic Acids Res. 2015:43:e17.

116. Xiao A, Wang Z, Hu Y, Wu Y, Luo Z, Yang Z, Zu Y, Li W, Huang P, Tong X, et al. Chromosomal deletions and inversions mediated by TALENs and CRISPR/Cas in zebrafish. Nucleic Acids Res. 2013;41:e141.

117. Lee B, Sahoo A, Marchica J, Holzhauser E, Chen X, Li JL, Seki T, Govindarajan SS, Markey FB, Batish M, et al. The long noncoding RNA SPRIGHTLY acts as an intranuclear organizing hub for pre-mRNA molecules. Sci Adv. 2017;3: e1602505.

118. Heskett M, Smith LG, Spellman P, Thayer MJ. Reciprocal monoallelic expression of ASAR IncRNA genes controls replication timing of human chromosome 6. RNA. 2019:732784.

119. Xing Z, Zhang Y, Liang K, Yan L, Xiang Y, Li C, Hu Q, Jin F, Putluri V, Putluri $\mathrm{N}$, et al. Expression of long noncoding RNA YIYA promotes glycolysis in breast cancer. Cancer Res. 2018;78:4524-32.

120. Aboudehen K, Farahani S, Kanchwala M, Chan SC, Avdulov S, Mickelson A, Lee D, Gearhart MD, Patel V, Xing C, Igarashi P. Long noncoding RNA Hoxb3os is dysregulated in autosomal dominant polycystic kidney disease and regulates mTOR signaling. J Biol Chem. 2018;293:9388-98.

121. Ye XT, Huang $H$, Huang WP, Hu WL. LnCRNA THOR promotes human renal cell carcinoma cell growth. Biochem Biophys Res Commun. 2018; 501:661-7.

122. Peng $L$, Pan $P$, Chen J, Yu X, Wu J, Chen Y. A tetracycline-inducible CRISPR/Cas9 system, targeting two long non-coding RNAs, suppresses the malignant behavior of bladder cancer cells. Oncol Lett. 2018;16: 4309-16.

123. Saeinasab M, Bahrami AR, González J, Marchese FP, Martinez D, Mowla SJ, Matin MM, Huarte M. SNHG15 is a bifunctional MYC-regulated noncoding locus encoding a IncRNA that promotes cell proliferation, invasion and drug resistance in colorectal cancer by interacting with AlF. J Exp Clin Cancer Res. 2019;38:172

124. Zhuo W, Liu Y, Li S, Guo D, Sun Q, Jin J, Rao X, Li M, Sun M, Jiang M, et al. Long noncoding RNA GMAN, up-regulated in gastric cancer tissues, is associated with metastasis in patients and promotes translation of Ephrin A1 by competitively binding GMAN-AS. Gastroenterology. 2019;156:676-91 e611.

125. Wang $X$, Yu H, Sun W, Kong J, Zhang L, Tang J, Wang J, Xu E, Lai M, Zhang $H$. The long non-coding RNA CYTOR drives colorectal cancer progression by interacting with NCL and Sam68. Mol Cancer. 2018;17:110.

126. Wen K, Yang L, Xiong T, Di C, Ma D, Wu M, Xue Z, Zhang X, Long L, Zhang W, et al. Critical roles of long noncoding RNAs in Drosophila spermatogenesis. Genome Res. 2016;26:1233-44.
127. Wei S, Chen H, Dzakah EE, Yu B, Wang X, Fu T, Li J, Liu L, Fang S, Liu W, Shan G. Systematic evaluation of C. elegans lincRNAs with CRISPR knockout mutants. Genome Biol. 2019;20:7.

128. Akay A, Jordan D, Navarro IC, Wrzesinski T, Ponting CP, Miska EA, Haerty W. Identification of functional long non-coding RNAs in C. elegans. BMC Biol. 2019:17:14.

129. Liu SJ, Nowakowski TJ, Pollen AA, Lui JH, Horlbeck MA, Attenello FJ, He D, Weissman JS, Kriegstein AR, Diaz AA, Lim DA. Single-cell analysis of long noncoding RNAs in the developing human neocortex. Genome Biol. 2016;17:67.

130. Field AR, Jacobs FMJ, Fiddes IT, Phillips APR, Reyes-Ortiz AM, LaMontagne E, Whitehead L, Meng V, Rosenkrantz JL, Olsen M, et al. Structurally conserved primate IncRNAs are transiently expressed during human cortical differentiation and influence cell-type-specific genes. Stem Cell Rep. 2019:12:245-57.

131. Yamazaki T, Fujikawa C, Kubota A, Takahashi A, Hirose T. CRISPRa-mediated NEAT1 IncRNA upregulation induces formation of intact paraspeckles. Biochem Biophys Res Commun. 2018;504:218-24.

132. Mazor G, Levin L, Picard D, Ahmadov U, Carén H, Borkhardt A, Reifenberger G, Leprivier G, Remke M, Rotblat B. The IncRNA TP73-AS1 is linked to aggressiveness in glioblastoma and promotes temozolomide resistance in glioblastoma cancer stem cells. Cell Death Dis. 2019;10:246.

133. Beermann J, Kirste D, Iwanov K, Lu D, Kleemiß F, Kumarswamy R, Schimmel K, Bär C, Thum T. A large shRNA library approach identifies IncRNA Ntep as an essential regulator of cell proliferation. Cell Death Differ. 2018;25:307.

134. Bester AC, Lee JD, Chavez A, Lee YR, Nachmani D, Vora S, Victor J, Sauvageau M, Monteleone $E$, Rinn $J$, et al. An integrated genome-wide CRISPRa approach to functionalize IncRNAs in drug resistance. Cell. 2018; 173:649-64 e620.

135. Lin N, Chang KY, Li Z, Gates K, Rana ZA, Dang J, Zhang D, Han T, Yang CS, Cunningham TJ, et al. An evolutionarily conserved long noncoding RNA TUNA controls pluripotency and neural lineage commitment. Mol Cell. 2014;53:1005-19.

136. Zhu S, Li W, Liu J, Chen CH, Liao Q, Xu P, Xu H, Xiao T, Cao Z, Peng J, et al. Genome-scale deletion screening of human long non-coding RNAs using a paired-guide RNA CRISPR-Cas9 library. Nat Biotechnol. 2016:34:1279-86.

137. Liu SJ, Horlbeck MA, Cho SW, Birk HS, Malatesta M, He D, Attenello FJ, Villalta JE, Cho MY, Chen Y, et al. CRISPRi-based genome-scale identification of functional long noncoding RNA loci in human cells. Science. 2017;355: eaah7111.

138. Haerty W, Ponting CP. Mutations within IncRNAs are effectively selected against in fruitfly but not in human. Genome Biol. 2013;14:R49.

139. Pang KC, Frith MC, Mattick JS. Rapid evolution of noncoding RNAs: lack of conservation does not mean lack of function. Trends Genet. 2006;22:1-5.

140. Nitsche A, Stadler PF. Evolutionary clues in IncRNAs. Wiley Interdiscip Rev RNA. 2017:8:e1376.

141. Nitsche A, Rose D, Fasold M, Reiche K, Stadler PF. Comparison of splice sites reveals that long noncoding RNAs are evolutionarily well conserved. RNA. 2015;21:801-12.

142. Hezroni H, Koppstein D, Schwartz MG, Avrutin A, Bartel DP, Ulitsky I. Principles of long noncoding RNA evolution derived from direct comparison of transcriptomes in 17 species. Cell Rep. 2015;11:1110-22.

143. Nobrega MA, Zhu Y, Plajzer-Frick I, Afzal V, Rubin EM. Megabase deletions of gene deserts result in viable mice. Nature. 2004;431:988-93.

144. Selleri L, Bartolomei MS, Bickmore WA, He L, Stubbs L, Reik W, Barsh GS. A Hox-embedded long noncoding RNA: is it all hot air? PLoS Genet. 2016;12: e1006485.

145. Li L, Helms JA, Chang HY. Comment on "Hotair is dispensable for mouse development". PLoS Genet. 2016;12:e1006406

146. Spadaro PA, Flavell CR, Widagdo J, Ratnu VS, Troup M, Ragan C, Mattick JS, Bredy TW. Long noncoding RNA-directed epigenetic regulation of gene expression is associated with anxiety-like behavior in mice. Biol Psychiatry. 2015;78:848-59.

147. Huarte M, Guttman M, Feldser D, Garber M, Koziol MJ, Kenzelmann-Broz D, Khalil AM, Zuk O, Amit I, Rabani M, et al. A large intergenic noncoding RNA induced by p53 mediates global gene repression in the p53 response. Cell. 2010;142:409-19.

148. Yang F, Zhang H, Mei Y, Wu M. Reciprocal regulation of HIF-1alpha and lincRNA-p21 modulates the Warburg effect. Mol Cell. 2014;53:88-100.

149. Bao X, Wu H, Zhu X, Guo X, Hutchins AP, Luo Z, Song H, Chen Y, Lai K, Yin $M$, et al. The $p 53$-induced lincRNA-p21 derails somatic cell reprogramming 
by sustaining $\mathrm{H} 3 \mathrm{~K} 9 \mathrm{me} 3$ and $\mathrm{CpG}$ methylation at pluripotency gene promoters. Cell Res. 2015;25:80-92.

150. Groff AF, Sanchez-Gomez DB, Soruco MML, Gerhardinger C, Barutcu AR, Li E, Elcavage L, Plana O, Sanchez LV, Lee JC, et al. In vivo characterization of Linc-p21 reveals functional cis-regulatory DNA elements. Cell Rep. 2016;16: 2178-86.

151. Miyagawa R, Tano K, Mizuno R, Nakamura Y, ljiri K, Rakwal R, Shibato J, Masuo Y, Mayeda A, Hirose T, Akimitsu N. Identification of cis- and transacting factors involved in the localization of MALAT-1 noncoding RNA to nuclear speckles. RNA. 2012;18:738-51.

152. Tripathi V, Ellis JD, Shen Z, Song DY, Pan Q, Watt AT, Freier SM, Bennett CF, Sharma A, Bubulya PA, et al. The nuclear-retained noncoding RNA MALAT1 regulates alternative splicing by modulating SR splicing factor phosphorylation. Mol Cell. 2010;39:925-38.

153. Ji P, Diederichs S, Wang W, Boing S, Metzger R, Schneider PM, Tidow N, Brandt B, Buerger $H$, Bulk E, et al. MALAT-1, a novel noncoding RNA, and thymosin beta4 predict metastasis and survival in early-stage non-small cell lung cancer. Oncogene. 2003;22:8031-41.

154. Yang L, Lin C, Liu W, Zhang J, Ohgi KA, Grinstein JD, Dorrestein PC, Rosenfeld MG. ncRNA-and Pc2 methylation-dependent gene relocation between nuclear structures mediates gene activation programs. Cell. 2011 147:773-88.

155. Bernard D, Prasanth KV, Tripathi V, Colasse S, Nakamura T, Xuan Z, Zhang $M Q$, Sedel F, Jourdren L, Coulpier F, et al. A long nuclear-retained noncoding RNA regulates synaptogenesis by modulating gene expression. EMBO J. 2010;29:3082-93.

156. Jin HY, Gonzalez-Martin A, Miletic AV, Lai M, Knight S, Sabouri-Ghomi M, Head SR, Macauley MS, Rickert RC, Xiao C. Transfection of microRNA mimics should be used with caution. Front Genet. 2015;6:340.

157. Jackson AL, Linsley PS. Recognizing and avoiding siRNA off-target effects for target identification and therapeutic application. Nat Rev Drug Discov. 2010; 9:57-67.

158. Jackson AL, Linsley PS. Noise amidst the silence: off-target effects of siRNAs? Trends Genet. 2004;20:521-4.

159. Persengiev SP, Zhu X, Green MR. Nonspecific, concentration-dependent stimulation and repression of mammalian gene expression by small interfering RNAs (siRNAs). RNA. 2004;10:12-8.

160. Lindow M, Vornlocher HP, Riley D, Kornbrust DJ, Burchard J, Whiteley LO, Kamens J, Thompson JD, Nochur S, Younis $\mathrm{H}$, et al. Assessing unintended hybridization-induced biological effects of oligonucleotides. Nat Biotechnol. 2012;30:920-3.

161. Kamola PJ, Kitson JD, Turner G, Maratou K, Eriksson S, Panjwani A, Warnock LC, Douillard Guilloux GA, Moores K, Koppe EL, et al. In silico and in vitro evaluation of exonic and intronic off-target effects form a critical element of therapeutic ASO gapmer optimization. Nucleic Acids Res. 2015;43:8638-50.

162. Stojic L, Lun ATL, Mangei J, Mascalchi P, Quarantotti V, Barr AR, Bakal C, Marioni JC, Gergely F, Odom DT. Specificity of RNAi, LNA and CRISPRi as loss-of-function methods in transcriptional analysis. Nucleic Acids Res. 2018;46:5950-66.

163. Jonchere V, Bennett D. Validating RNAi phenotypes in Drosophila using a synthetic RNAi-resistant transgene. PLoS One. 2013;8:e70489.

164. Olejniczak M, Urbanek MO, Jaworska E, Witucki L, Szczesniak MW, Makalowska I, Krzyzosiak WJ. Sequence-non-specific effects generated by various types of RNA interference triggers. Biochim Biophys Acta. 2016;1859:306-14.

165. Burel SA, Hart CE, Cauntay P, Hsiao J, Machemer T, Katz M, Watt A, Bui HH, Younis H, Sabripour M, et al. Hepatotoxicity of high affinity gapmer antisense oligonucleotides is mediated by RNase $\mathrm{H} 1$ dependent promiscuous reduction of very long pre-mRNA transcripts. Nucleic Acids Res. 2016:44:2093-109.

166. Watts JK, Corey DR. Gene silencing by siRNAs and antisense oligonucleotides in the laboratory and the clinic. J Pathol. 2012;226:365.

167. Kok FO, Shin M, Ni CW, Gupta A, Grosse AS, van Impel A, Kirchmaier BC, Peterson-Maduro J, Kourkoulis G, Male I, et al. Reverse genetic screening reveals poor correlation between morpholino-induced and mutant phenotypes in zebrafish. Dev Cell. 2015;32:97-108.

168. Kleinstiver BP, Pattanayak V, Prew MS, Tsai SQ, Nguyen NT, Zheng Z, Joung JK. High-fidelity CRISPR-Cas9 nucleases with no detectable genome-wide off-target effects. Nature. 2016;529:490-5.

169. Kuscu C, Arslan S, Singh R, Thorpe J, Adli M. Genome-wide analysis reveals characteristics of off-target sites bound by the Cas9 endonuclease. Nat Biotechnol. 2014;32:677-83.
170. Zuo E, Sun Y, Wei W, Yuan T, Ying W, Sun H, Yuan L, Steinmetz LM, Li Y, Yang $\mathrm{H}$. Cytosine base editor generates substantial off-target singlenucleotide variants in mouse embryos. Science. 2019;364:289-92.

171. Jin S, Zong Y, Gao Q, Zhu Z, Wang Y, Qin P, Liang C, Wang D, Qiu JL, Zhang $F$, Gao C. Cytosine, but not adenine, base editors induce genome-wide offtarget mutations in rice. Science. 2019;364:292-5.

172. Ramilowski J, Yip CW, Agrawal S, Chang J-C, Ciani Y, Kulakovskiy IV, Mendez M, Ooi JLC, Ouyang JF, Parkinson N, et al. Functional annotation of human long non-coding RNAs via molecular phenotyping. bioRxiv. 2019:700864.

173. Ulitsky I, Shkumatava A, Jan CH, Sive H, Bartel DP. Conserved function of lincRNAs in vertebrate embryonic development despite rapid sequence evolution. Cell. 2011;147:1537-50.

174. Engreitz JM, Haines JE, Perez EM, Munson G, Chen J, Kane M, McDonel PE, Guttman M, Lander ES. Local regulation of gene expression by IncRNA promoters, transcription and splicing. Nature. 2016;539:452-5.

175. Lyle R, Watanabe D, te Vruchte D, Lerchner W, Smrzka OW, Wutz A, Schageman J, Hahner L, Davies C, Barlow DP. The imprinted antisense RNA at the lgf2r locus overlaps but does not imprint Mas1. Nat Genet. 2000;25:19-21.

176. Zhang F, Lupski JR. Non-coding genetic variants in human disease. Hum Mol Genet. 2015;24:R102-10.

177. Visscher PM, Brown MA, McCarthy MI, Yang J. Five years of GWAS discovery. Am J Hum Genet. 2012;90:7-24.

178. Liu S, Liu Y, Zhang Q, Wu J, Liang J, Yu S, Wei GH, White KP, Wang X. Systematic identification of regulatory variants associated with cancer risk. Genome Biol. 2017;18:194.

179. Laurent GS, Vyatkin Y, Kapranov P. Dark matter RNA illuminates the puzzle of genome-wide association studies. BMC Med. 2014;12:97.

180. Pasmant E, Sabbagh A, Vidaud M, Bièche I. ANRIL, a long, noncoding RNA, is an unexpected major hotspot in GWAS. FASEB J. 2011;25:444-8.

181. Holdt LM, Hoffmann S, Sass K, Langenberger D, Scholz M, Krohn K, Finstermeier K, Stahringer A, Wilfert W, Beutner F, et al. Alu elements in ANRIL non-coding RNA at chromosome 9p21 modulate atherogenic cell functions through trans-regulation of gene networks. PLoS Genet. 2013;9: e1003588.

182. Reyes-Gibby CC, Wang J, Silvas MRT, Robert KY, Hanna EY, Shete S. Genome-wide association study suggests common variants within RP11634B7. 4 gene influencing severe pre-treatment pain in head and neck cancer patients. Sci Rep. 2016;6:34206.

183. Hon CC, Ramilowski JA, Harshbarger J, Bertin N, Rackham OJ, Gough J, Denisenko E, Schmeier S, Poulsen TM, Severin J, et al. An atlas of human long non-coding RNAs with accurate 5' ends. Nature. 2017;543:199-204.

184. Mercer TR, Dinger ME, Sunkin SM, Mehler MF, Mattick JS. Specific expression of long noncoding RNAs in the mouse brain. Proc Natl Acad Sci U S A. 2008;105:716-21.

185. Liu S, Wang Z, Chen D, Zhang B, Tian RR, Wu J, Zhang Y, Xu K, Yang LM, Cheng C, et al. Annotation and cluster analysis of spatiotemporal- and sex-related IncRNA expression in rhesus macaque brain. Genome Res. 2017;27:1608-20.

186. Pauli A, Valen E, Lin MF, Garber M, Vastenhouw NL, Levin JZ, Fan L, Sandelin A, Rinn JL, Regev A, Schier AF. Systematic identification of long noncoding RNAs expressed during zebrafish embryogenesis. Genome Res. 2012;22:577-91.

187. Tang Z, Wu Y, Yang Y, Yang YT, Wang Z, Yuan J, Yang Y, Hua C, Fan X, Niu $G$, et al. Comprehensive analysis of long non-coding RNAs highlights their spatio-temporal expression patterns and evolutional conservation in Sus scrofa. Sci Rep. 2017;7:43166.

188. Nowak MA, Boerlijst MC, Cooke J, Smith JM. Evolution of genetic redundancy. Nature. 1997;388:167-71.

189. Gu Z, Steinmetz LM, Gu X, Scharfe C, Davis RW, Li WH. Role of duplicate genes in genetic robustness against null mutations. Nature. 2003;421:63-6.

190. Osterwalder M, Barozzi I, Tissieres V, Fukuda-Yuzawa Y, Mannion BJ, Afzal SY, Lee EA, Zhu Y, Plajzer-Frick I, Pickle CS, et al. Enhancer redundancy provides phenotypic robustness in mammalian development. Nature. 2018;554:239-43.

191. Bouché N, Bouchez D. Arabidopsis gene knockout: phenotypes wanted. Curr Opin Plant Biol. 2001;4:111-7.

192. Berthet C, Aleem E, Coppola V, Tessarollo L, Kaldis P. Cdk2 knockout mice are viable. Curr Biol. 2003;13:1775-85.

193. Rane SG, Dubus P, Mettus RV, Galbreath EJ, Boden G, Reddy EP, Barbacid M. Loss of Cdk4 expression causes insulin-deficient diabetes and Cdk4 activation results in beta-islet cell hyperplasia. Nat Genet. 1999;22:44-52.

194. Berthet C, Klarmann KD, Hilton MB, Suh HC, Keller JR, Kiyokawa H, Kaldis P. Combined loss of $\mathrm{Cdk} 2$ and $\mathrm{Cdk} 4$ results in embryonic lethality and $\mathrm{Rb}$ hypophosphorylation. Dev Cell. 2006;10:563-73. 
195. Schwarz DG, Griffin CT, Schneider EA, Yee D, Magnuson T. Genetic analysis of sorting nexins 1 and 2 reveals a redundant and essential function in mice. Mol Biol Cell. 2002;13:3588-600.

196. Liang X, Zhou Q, Li X, Sun Y, Lu M, Dalton N, Ross J, Chen J. PINCH1 plays an essential role in early murine embryonic development but is dispensable in ventricular cardiomyocytes. Mol Cell Biol. 2005;25:3056-62.

197. Stanchi F, Bordoy R, Kudlacek O, Braun A, Pfeifer A, Moser M, Fassler R. Consequences of loss of PINCH2 expression in mice. J Cell Sci. 2005:118: 5899-910.

198. Liang X, Sun Y, Ye M, Scimia MC, Cheng H, Martin J, Wang G, Rearden A Wu C, Peterson KL, et al. Targeted ablation of PINCH1 and PINCH2 from murine myocardium results in dilated cardiomyopathy and early postnatal lethality. Circulation. 2009;120:568-76.

199. Sasaki YT, Ideue T, Sano M, Mituyama T, Hirose T. MENepsilon/beta noncoding RNAs are essential for structural integrity of nuclear paraspeckles. Proc Natl Acad Sci U S A. 2009;106:2525-30.

200. Lewejohann L, Skryabin BV, Sachser N, Prehn C, Heiduschka P, Thanos S, Jordan U, Dell'Omo G, Vyssotski AL, Pleskacheva MG, et al. Role of a neuronal small non-messenger RNA: behavioural alterations in BC1 RNAdeleted mice. Behav Brain Res. 2004;154:273-89.

201. Skryabin BV, Sukonina V, Jordan U, Lewejohann L, Sachser N, Muslimov Tiedge $\mathrm{H}$, Brosius J. Neuronal untranslated BC1 RNA: targeted gene elimination in mice. Mol Cell Biol. 2003;23:6435-41.

202. Pearson H. Surviving a knockout blow. Nature. 2002;415:8-9.

203. Abudayyeh OO, Gootenberg JS, Essletzbichler P, Han S, Joung J, Belanto JJ, Verdine V, Cox DBT, Kellner MJ, Regev A, et al. RNA targeting with CRISPRCas13. Nature. 2017:550:280-4.

204. Xu D, Cai Y, Tang L, Han X, Gao F, Cao H, Qi F, Kapranov P. A CRISPR/Cas13based approach demonstrates biological relevance of vlinc class of long non-coding RNAs in anticancer drug response. Sci Rep. 2020;10:1794.

205. Tuck AC, Natarajan KN, Rice GM, Borawski J, Mohn F, Rankova A, Flemr M, Wenger A, Nutiu R, Teichmann S, Buhler M. Distinctive features of lincRNA gene expression suggest widespread RNA-independent functions. Life Sci Alliance. 2018;1:e201800124.

206. Ivaldi MS, Diaz LF, Chakalova L, Lee J, Krivega I, Dean A. Fetal Y-globin genes are regulated by the BGLT3 long noncoding RNA locus. Blood. 2018;132: 1963-73.

207. Yin $Y$, Yan $P$, Lu J, Song G, Zhu $Y$, Li Z, Zhao $Y$, Shen B, Huang $X$, Zhu $H$, et al. Opposing roles for the IncRNA haunt and its genomic locus in regulating HOXA gene activation during embryonic stem cell differentiation. Cell Stem Cell. 2015;16:504-16.

208. Maamar H, Cabili MN, Rinn J, Raj A. linc-HOXA1 is a noncoding RNA that represses Hoxa1 transcription in cis. Genes Dev. 2013;27:1260-71.

209. Kapranov P, St Laurent G, Raz T, Ozsolak F, Reynolds CP, Sorensen PH, Reaman G, Milos P, Arceci RJ, Thompson JF, Triche TJ. The majority of total nuclear-encoded non-ribosomal RNA in a human cell is 'dark matter' unannotated RNA. BMC Biol. 2010;8:149.

210. Yue M, Ogawa Y. CRISPR/Cas9-mediated modulation of splicing efficiency reveals short splicing isoform of Xist RNA is sufficient to induce $X$ chromosome inactivation. Nucleic Acids Res. 2017;46:e26.

211. Consortium EP. An integrated encyclopedia of DNA elements in the human genome. Nature. 2012;489:57-74.

212. Lonsdale J, Thomas J, Salvatore M, Phillips R, Lo E, Shad S, Hasz R, Walters G, Garcia F, Young N, et al. The genotype-tissue expression (GTEx) project. Nat Genet. 2013;45:580-5.

213. Cancer Genome Atlas Research N, Weinstein JN, Collisson EA, Mills GB, Shaw KR, Ozenberger BA, Ellrott K, Shmulevich I, Sander C, Stuart JM. The cancer genome atlas pan-cancer analysis project. Nat Genet. 2013;45:1113-20.

214. Mouse EC, Stamatoyannopoulos JA, Snyder M, Hardison R, Ren B, Gingeras T, Gilbert DM, Groudine M, Bender M, Kaul R, et al. An encyclopedia of mouse DNA elements (Mouse ENCODE). Genome Biol. 2012;13:418.

215. Consortium F, the RP, Clst, Forrest AR, Kawaji H, Rehli M, Baillie JK, de Hoon MJ, Haberle V, Lassmann T, et al. A promoter-level mammalian expression atlas. Nature. 2014;507:462-70.

216. Karner HM, Webb CH, Carmona S, Liu Y, Lin B, Erhard M, Chan D, Baldi P, Spitale RC, Sun S. Functional conservation of IncRNA JPX despite sequence and structural divergence. J Mol Biol. 2020;432:283-300.

217. Anderson DM, Anderson KM, Chang CL, Makarewich CA, Nelson BR, McAnally JR, Kasaragod P, Shelton JM, Liou J, Bassel-Duby R, Olson EN. A micropeptide encoded by a putative long noncoding RNA regulates muscle performance. Cell. 2015;160:595-606.
218. Chugunova A, Loseva E, Mazin P, Mitina A, Navalayeu T, Bilan D, Vishnyakova P, Marey M, Golovina A, Serebryakova M, et al. LINC00116 codes for a mitochondrial peptide linking respiration and lipid metabolism. Proc Natl Acad Sci U S A. 2019;116:4940-5.

219. Huang JZ, Chen M, Chen, Gao XC, Zhu S, Huang H, Hu M, Zhu H, Yan GR. A peptide encoded by a putative IncRNA HOXB-AS3 suppresses colon cancer growth. Mol Cell. 2017;68:171-84 e176.

\section{Publisher's Note}

Springer Nature remains neutral with regard to jurisdictional claims in published maps and institutional affiliations. 